Canadian

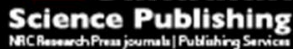

Canadian Geotechnical Journal Revue canadienne de géotechnique

\title{
Investigation of plant growth and transpiration-induced matric suction under mixed grass-tree conditions
}

\begin{tabular}{|r|l|}
\hline Journal: & Canadian Geotechnical Journal \\
\hline Manuscript ID & cgj-2016-0226.R1 \\
\hline Danuscript Type: & Article \\
\hline Complete List of Authors: & $\begin{array}{l}\text { Ni, Junjun; The Hong Kong University of Science and Technology, } \\
\text { Department of Civil and Environmental Engineering } \\
\text { Leung, Anthony; University of Dundee, Division of Civil Engineering } \\
\text { Ng, C.W.W.; The Hong Kong University of Science and Technology, } \\
\text { Department of Civil and Environmental Engineering } \\
\text { So, Pui San; The Hong Kong University of Science and Technology, } \\
\text { Department of Civil and Environmental Engineering }\end{array}$ \\
\hline Keyword: & $\begin{array}{l}\text { mixed-species planting, plant spacing, plant growth, evapotranspiration, } \\
\text { matric suction }\end{array}$ \\
\hline \multicolumn{2}{|c}{} \\
\hline
\end{tabular}




\title{
Investigation of plant growth and transpiration-induced matric suction under mixed grass-tree conditions
}

\author{
J. J. Ni, A. K. Leung*, C. W. W. Ng and P. S. So
}

Name: Mr Jun Jun, NI

Affiliation: Research student, Department of Civil and Environmental Engineering, Hong Kong University of Science and Technology

Address: Department of Civil and Environmental Engineering, Hong Kong University of Science and Technology, Clear Water Bay, Kowloon, Hong Kong

Name: *Dr Anthony Kwan, LEUNG (Corresponding author)

Affiliation: Lecturer, School of Science and Engineering, University of Dundee

Address: School of Science and Engineering, University of Dundee, Dundee, UK, DD1 4HN

Email: aleung@dundee.ac.uk

Name: Dr Charles Wang Wai, NG

Affiliation: Chair Professor, Department of Civil and Environmental Engineering, Hong Kong University of Science and Technology

Address: Department of Civil and Environmental Engineering, Hong Kong University of Science and Technology, Clear Water Bay, Kowloon, Hong Kong

Name: Mr Pui San, SO

Affiliation: Research student, Department of Civil and Environmental Engineering, Hong Kong University of Science and Technology

Address: Department of Civil and Environmental Engineering, Hong Kong University of Science and Technology, Clear Water Bay, Kowloon, Hong Kong 


\section{Abstract}

Although evapotranspiration-induced matric suction for single species has been widely studied, little is known about how mixed-species planting would affect the plant growth and induced matric suction. This study aims to explore the effects of grass-tree interaction on their growth and induced matric suction during evapotranspiration (ET) and rainfalls. Field monitoring was carried out to measure matric suction responses in compacted soil that was vegetated with (i) single tree species, Schefflera heptaphylla and (ii) mixed species of the trees and a grass species, Cynodon dactylon. In each condition, three tree spacings (120, 180 and $240 \mathrm{~mm})$ were planted. When tree spacing increased from 120 to $240 \mathrm{~mm}$, the peak tree root area index (RAI, for fine roots with diameter $<2 \mathrm{~mm}$ ) decreased by $16 \%$, but the peak grass RAI increased by $29 \%$. At mixed planting plots, the ET-induced peak matric suction for tree spacing of $240 \mathrm{~mm}$ was $20 \%$ higher than that for spacing of $180 \mathrm{~mm}$ because of increased contribution of grass root-water uptake as the trees were more widely spaced. Without grass, a reverse trend was observed as tree-tree interaction reduced at wide spacings. The peak ET-induced matric suction had a significant linear correlation with RAI. During rainfalls, the highest matric suction was preserved for the case of $240 \mathrm{~mm}$ spacing due to the greatest reduction of soil hydraulic conductivity by roots.

Key words: mixed-species planting, plant spacing, plant growth, evapotranspiration, matric suction 


\section{Introduction}

Soil bioengineering using vegetation has been recognized as an ecologically- and environmentally-friendly technique that can affect the stability of geotechnical infrastructure such as man-made/engineered slopes. In order to increase the ecological values and biodiversity, it is common to have multiple types of species, such as grass and tree, grown on these engineering structures. Grass that has relatively shallow root system may be effective for soil erosion control, while tree has relatively stronger and deeper root system which may be used for mechanical soil stabilisation. Despite of rather different root systems, transpiration would happen for both types of species, causing a change in matric suction (Pollen-bankhead and Simon 2010; Garg et al. 2015b; Leung et al. 2015b; Ng et al. 2013, 2014, 2016a, b) and consequently the soil hydrology (Simon and Collison 2002; Smethurst et al. 2015; Ng et al. 2016c). The increase in matric suction due to plant transpiration would result in a decrease in soil hydraulic conductivity ( $\mathrm{Ng}$ and Leung 2012) and also an increase in soil shear strength ( $\mathrm{Ng}$ and Menzies 2007). The hydrological effects of plant transpiration could thus affect both the hydrology and the stability of an earthen infrastructure.

When applying soil bioengineering technique using multiple species, it is crucial to determine any optimum plant spacing so as to maximise the beneficial effects of plant transpiration, while at the same time minimising any significant stresses to plant growth due to plant-plant interaction. Previous studies have shown that the spacing of one single species could discourage plant growth and hence reduce both of its aboveand below-ground biomasses (Azam-Ali et al. 1984; Darawsheh et al. 2009; Ng et al. 
2016b). This is owing to increased competition for water, nutrient and light resources from neighbouring plants (Farnham 2001; Green et al. 2001; Benomar et al. 2012). Under mixed grass-tree conditions, the tree spacing has shown to play a significant role on the growth and biomass production of grass. This is because of overlaps of the trees' and grasses' root systems and also shading of sunlight by the canopies of neighbouring trees (Scholes and Archer 1997; Ludwig et al. 2004). Some studies (Grouzis and Akpo 1997; Schade et al. 2003) found an increase in grass biomass due to the beneficial alteration of resource availability and microclimatic conditions by trees. However, some (Eastham et al. 1990; Razados-Lorenzo et al. 2007) reported the opposite because of the less solar radiation received by grass and the intensive grass-tree competition for soil resources, such as water and nutrients. Clearly, the effects of tree spacing on grass biomass production are not conclusive and warrant more investigation, especially for the case under mixed grass-tree conditions.

Plant spacing affects not only the plant growth but may also plant root-water uptake, and hence the amount of transpiration-induced matric suction (Azam-Ali et al. 1984; Ng et al. 2016b). Recently, Ng et al. (2016b) has studied how the spacing of one single tree species affected matric suction responses. They concluded that closer tree spacing was more beneficial because (i) higher transpiration-induced matric suction was induced due to intense tree-tree competition and (ii) higher matric suction was preserved below the tree root zone during rainfall. At present, it is not well understood whether the same conclusions can be drawn under mixed tree-grass conditions. It is also not clear whether tree spacing would affect the grass and tree traits, some of 
which are known to have direct influences on plant root-water uptake and induced matric suction (López et al. 2001; Garg et al. 2015b; Ng et al. 2016a, b).

The objective of this study is to carry out field monitoring (i) to investigate the effects of tree spacing on any change in the growth condition of grass and trees and then (ii) to quantify and compare induced matric suction with and without the presence of grass under different tree spacing. To assist the interpretation of the field test data, any change in soil hydraulic conductivity due to different tree spacings was measured. In addition, plant traits including leaf area index (LAI) and root area index (RAI) were measured and used to interpret the matric suction induced during ET and rainfall.

\section{Materials and methods}

\section{Site description}

The field monitoring was carried out at the Hong Kong University of Science and Technology (HKUST) Eco-park at LOHAS Park, Hong Kong. The site has two purpose-build research facilities, namely a $2 \mathrm{~m}$-height vegetated embankment (as was tested by Leung et al. (2015a) and Garg et al. (2015a)) and a $10 \mathrm{~m}$ x 6 m (in plan) flat compacted ground. The field monitoring work reported in this paper was performed on the flat ground. The groundwater table was identified at $4.5 \mathrm{~m}$ depth from the surface of the flat ground. The monitoring period was from $14^{\text {th }}$ to $29^{\text {th }}$ April 2015 (i.e., 16 days). The average air temperature, relative humidity and solar radiation during the monitoring period were $23.6{ }^{\circ} \mathrm{C}, 77 \%$ and $15.74 \mathrm{MJ} / \mathrm{m}^{2}$, respectively. 
The flat ground was compacted with completely decomposed granite (CDG), which is a soil type commonly found in tropical and sub-tropic regions of the world such as Hong Kong, South Korea and Brazil. The average contents of gravel, sand, silt and clay of the CDG were $9.5 \%, 83.1 \% 5.1 \%$ and $2.3 \%$, respectively. The liquid limit and plastic limit were $22 \%-30 \%$ and $42 \%-46 \%$, respectively. Based on the measured particle-size distribution and the Atterberg limit, the CDG was classified as well-graded sand with silt (SW-SM), according to the Unified Soil Classification System (USCS; ASTM 2010a). The pH of the CDG is 6.0. Nutrient tests following the measurement methods suggested by Sparks et al (1996) and Buhrke et al. (1998) show that the contents of $\mathrm{N}, \mathrm{P}$ (that are extractable by plants) in the CDG soil are 0.76 , $0.53 \mathrm{mg} / \mathrm{kg}$, respectively. On the other hand, the contents of total $\mathrm{C}, \mathrm{K}$ and $\mathrm{Ca}$ are $1.2 \%, 7.0 \%$ and $0.96 \%$, respectively. The CDG was compacted to a dry density of 1.8 $\mathrm{g} / \mathrm{cm}^{3}$, which corresponded to a relative compaction of $95 \%$. It has been shown that under this compaction level, the species tested in this study (i.e., Schefflera heptaphylla and Cynodon dactylon) were able to grow well in both the field and laboratory conditions (Ng et al. 2014, 2016b; Garg et al. 2015a, b; Leung et al. 2015a, b). Leung et al. (2015a) reported the soil-water retention curve of the CDG. It was found that the air-entry value of the CDG was $1-2 \mathrm{kPa}$. The field capacity was $20-$ $22 \%$, corresponding to the matric suction of $23-28 \mathrm{kPa}$.

In this field study, a tree species (Schefflera heptaphylla, also known as Ivy tree) and a grass species (Cynodon dactylon, also known as Bermuda grass) were selected for testing. These two species were selected because of their commonness in many 
parts of the Asia and also due to their high ability of drought tolerant (Hau and Corlett 2003). Both species were ecologically suitable for slope rehabilitation and reforestation at warm climates of the world (GEO 2011). Before transplantation, grass seeds were grown at a nursery for three months before the commencement of the field monitoring work. Tree individuals with similar heights were supplied by Tung Kee Garden Horticulture Ltd in Hong Kong. The characteristics of both the selected trees and grasses before transplantation to the site are summarised in Table 1.

\section{Test setup and instrumentation}

The compacted ground was divided into four test plots, each with $1.5 \mathrm{~m} \mathrm{x} 1.5 \mathrm{~m}$ area in plan. Three test plots were vegetated with the selected grass and tree species, while the remaining plot was left bare for reference. The three plots were covered with turf of $C$. dactylon. The initial length of grass shoot was $25 \pm 12 \mathrm{~mm}$. Then, tree individuals with a similar height of $600 \pm 38 \mathrm{~mm}$ were transplanted to the three vegetated plots with three different tree spacings $(120,180$ and $240 \mathrm{~mm})$. Because the maximum lateral spread of tree roots was $92-120 \mathrm{~mm}$, the minimum spacing 120 mm selected was to avoid overlaps of root systems. In total, 240 tree individuals were transplanted to the three vegetated plots. Before the start of the field monitoring, the vegetation in all three plots was grown for four months and watered every three days in order to maintain the average matric suction similar to that at field capacity of the CDG. The irrigation schedule was favourable for the plant growth. The growth duration considered was sufficient for root establishment with the surrounding soil 
after transplantation (Wang et al. 2007). During the four-month growing period, leaf area index (LAI) of both the trees and grasses were measured every two months, following the same method described by $\mathrm{Ng}$ et al. (2016b). LAI is a dimensionless index that is defined as the overall leaf area over the projected canopy area in plan.

Figure 1 shows the instrumentation plan of the field monitoring. In the centre of each plot, an array (Array I) of three jet-fill tensiometers (JFT) was installed at 100, 250 and $450 \mathrm{~mm}$ depths. Prior to installation, their ceramic tips and plastic tubes were fully saturated and filled with de-aired water. Due to the possibility of cavitation inside each JFT when matric suction approaches $90 \mathrm{kPa}$, two heat dissipation sensors (HDSs) were installed at 100 and $250 \mathrm{~mm}$ depths right next to the JFTs. Each HDS could measure matric suction up to $2500 \mathrm{kPa}$ (Fredlund and Wong 1989). HDS has a porous ceramic body, which has a hypodermic needle that contains a heating element and a thermocouple. When matric suction increases, water inside the ceramic body would flow to the surrounding soil due to a hydraulic head difference, resulting in a decrease in the thermal conductivity of the ceramic body. Depending on the thermal conductivity, part of the heat released by the heating element would dissipate through the ceramic body. The remained heat inside the ceramic body would lead to an increase in temperature $(\Delta \mathrm{T})$, which would be measured by the thermocouple. Matric suction can hence be correlated with $\Delta \mathrm{T}$ through a calibration curve. Each HDS was calibrated in the laboratory using a pressure plate for a range of matric suction from 0 to $400 \mathrm{kPa}$. The ceramic block of each HDS was placed in contact with the ceramic disk that was fully saturated with de-aired water and embedded at the base of the 
pressure plate. Each HDS was then subjected to two cycles of drying and wetting by controlling the air pressure applied inside the pressure plate, while maintaining the water pressure to be atmospheric. The calibration shows that when matric suction decreases to values lower than the air-entry value (AEV) of the ceramic block (i.e. 15 $\mathrm{kPa}$ ), nearly the same minimum $\Delta \mathrm{T}$ would be recorded. At these matric suctions, water content change in the ceramic block would be negligible. This means that the thermal conductivity of the ceramic block remained essentially unchanged and the measured $\Delta \mathrm{T}$ thus maintains at the same minimum value. This casts the lower limit of matric suction measurement (i.e. $15 \mathrm{kPa}$ ) made by each HDS. When matric suction is higher than $15 \mathrm{kPa}$, a linear relationship between suction (in logarithm scale) and $\Delta \mathrm{T}$ can be identified. Moreover, it is found that despite of the porosity of the ceramic of a HDS, the effect of hysteresis on the calibration curves is negligible after the first drying/wetting cycle, consistent with the observation reported by Leung and $\mathrm{Ng}$ (2013) who calibrated the same model of HDS for different soil types using the identical calibration method as this study. After installing the JFTs and HDSs, the gap between each sensor and the surrounding soil was backfilled with cement to prevent any preferential water flow. In order to take into account any effects of natural variability of plants on matric suction responses in three vegetated plots, two additional arrays of JFTs (Array II and III) were installed at locations about $500 \mathrm{~mm}$ away from Array I of the same plot. In these two arrays, two JFTs were installed at 100 and $250 \mathrm{~mm}$ depths. Unless stated otherwise, the term suction is used to refer to as matric suction. 


\section{Test procedures}

In each plot, two-stage tests were performed. The first stage was to test on the mixed-species grounds. The tests considering the tree spacing of 120, 180 and 240 mm were denoted as M120, M180 and M240, respectively. Prior to testing, the soil was wetted by water ponding at the ground surface until all JFTs showed zero reading. All plots were then left exposed to the atmosphere for monitoring for seven days from $14^{\text {th }}$ to $21^{\text {th }}$ April 2015. Any changes in suction were monitored. During the monitoring period on the $6^{\text {th }}-7^{\text {th }}$ days, two rainfall events happened. The first and second events had a total amount of 41 and $58 \mathrm{~mm}$, respectively. The corresponding peak rainfall intensity was 9 and $12 \mathrm{~mm} / \mathrm{hr}$. At the end of the monitoring, grass shoots in all plots were cut and removed carefully without affecting the shoots of trees and the root systems of both the trees and grasses. After grass removal, the second stage of testing commenced. The tests with tree spacing of 120, 180 and $240 \mathrm{~mm}$ were denoted as S120, S180 and S240, respectively. Similarly, all pots were firstly wetted with water, and then followed by another seven-day of monitoring from $22^{\text {th }}$ to $29^{\text {th }}$ April 2015. On $27^{\text {th }}$ April 2015 (i.e., the $6^{\text {th }}$ day), rainfall with a total amount of $31 \mathrm{~mm}$ happened, with a peak intensity of $10 \mathrm{~mm} / \mathrm{hr}$.

After the two-stage field monitoring, soil cores from depth 0 to $100 \mathrm{~mm}$ within the root zone were sampled from both the vegetated and bare plots for measuring the values of saturated hydraulic conductivity $\left(k_{s}\right)$ in the laboratory. All soil cores were sampled using a cylindrical core cutter, which was $76 \mathrm{~mm}$ in diameter and $100 \mathrm{~mm}$ in height. The cutter was vertically penetrated into the ground to a depth of $100 \mathrm{~mm}$. 
Three replicates were collected from each vegetated plot and one from the bare plot (i.e., 10 cores in total). Each soil core was then extruded from the cutter in the laboratory and was used for testing the $k_{s}$ through falling head method according to ASTM D5084 (2010b). Each soil specimen was saturated with de-aired water in a permeameter. In order to provide good contact between the sample membrane and the sample surface and hence to prevent preferential flow between them, an effective cell pressure of $2 \mathrm{kPa}$ was applied. When the Skempton B-value was higher than 95\% during saturation, the measurements of $k_{s}$ started. A water head of $100 \mathrm{~mm}$ was applied at the upper hydraulic boundary of each sample, resulting in a total head of $200 \mathrm{~mm}$. The total head at the bottom hydraulic boundary of each sample was maintained zero, resulting in an applied hydraulic gradient of two. By Darcy's law, the $k_{s}$ of all 10 soil specimens were determined. After the determination of $k_{s}$, the dry density of each soil core was measured. It was found that the dry density of the laboratory sample was less than $2 \%$ difference to that found in the field. It is thus reasonable to use the laboratory measured $k_{s}$ to interpret field suction responses.

The values of root area index (RAI) of all the trees and grasses were determined after the field monitoring. RAI is a dimensionless index that is defined as the ratio between the total root surface area of fine roots (i.e., those with diameter $<2 \mathrm{~mm}$ that are responsible for root water uptake; Jackson et al. 1997) within a given depth and the cross-section area of the root volume in plan (Francour and Semroud 1992). This index is an indication of the ability of root water uptake of plant roots (Garg et al. 2015a; Ng et al. 2016b). In the field, roots were excavated using spades and shovels, 
following the procedures adopted by Reubens (2010). In order to minimize disturbance of roots, the excavated width was wider than the maximum lateral spread of the root systems while the excavated depth was deeper than the root zone. The excavated soil block that contained the entire root system was then transported to the laboratory for root washing. Soil particles attached to the roots were washed away using a hydroneumatic-elutriation based apparatus (Smucker et al. 1982). After placing the soil block into the washing chamber of the apparatus, the soil was dispersed by a hydrovortex that was produced by pressurized jets of water. Roots were then separated from soil particles by flotation in a flow of small air bubbles in a horizontal tube. The soil particles left in the chamber were then evacuated through an exhaust. It is a much more efficient method, which gives results that are statistically similar to the tedious method of separation using hands. More detailed working principle of the hydroneumatic-elutriation based apparatus can be found in Smucker et al. (1982) and Chotte et al. (1995). Then, RAI was measured by using image analysis (Image J; Rasband 2011). High-resolution images were taken $360^{\circ}$ around each root system to obtain a three-dimensional (3-D) image. The 3-D image was then discretized into grids with equal pixel size (12 pixels per unit mm of length in this case). The total surface area of fine roots at a given depth range can then be calculated by counting the total number of grids containing fine roots. Finally, by dividing the total surface area of fine roots at a given depth by planar cross-sectional area of the soil, RAI at any depth was determined. 


\section{Results and discussion}

\section{Observed root systems of tree and grass}

Figure 2(a) shows the effects of tree spacing on the change in the tree root system. As the tree spacing decreased from 240 to $120 \mathrm{~mm}$, the size of root volume decreased by around $30 \%$. This is likely because when the tree spacing was closer, there was increased tree-tree competition, which might have suppressed the growth of tree roots, resulting in a smaller size of root volume. During the careful excavation of tree roots, evident decayed roots were identified for the case of close tree spacing of $120 \mathrm{~mm}$ as a result of intense tree-tree competition (Goldberg and Miller 1990; Ng et al. 2016b). The observed decay roots existed in dark brown or black in colour, which is visually distinguishable from whitish live roots. Also, the decay roots were much limper than fresh roots, which are normally non-brittle and crisp. When pulling a decayed root, a small force would break the circumference tissue rather easily, leaving only the central strand of water conducting tissue. On the contrary, relatively few decayed roots were found for the cases with wider spacing.

Figure 2(b) shows the changes in grass shoots and roots under the effects of tree spacing. The grasses grown under the closest tree spacing of $120 \mathrm{~mm}$ have $\sim 48 \%$ shorter shoots and $\sim 45 \%$ shorter roots than those grown under widest tree spacing of $240 \mathrm{~mm}$ (Table 1). Decay of grass roots was also found for the case of $120 \mathrm{~mm}$ tree spacing. The observed reduced grass growth and root decay was likely because of the shading of sunlight due to the overlaps of canopies between neighbouring trees (Scholes and Archer 1997; Ludwig et al. 2004). Intense grass-tree competition for soil 
resources, such as water and nutrients, due to close tree spacing might also reduce the production of the above- and below-ground biomass of grass (Razados-Lorenzo et al. 2007). This suggests that for the selected grasses and trees in this study, the competition between them have outweighed the beneficial effects of trees (i.e., alteration of resource availability and microclimatic conditions; Grouzis and Akpo 1997; Schade et al. 2003) on grass growth.

\section{Measured plant traits}

Figure 3 shows the measured variations of the LAI of grass and tree with time during the four-month growing period. The initial mean LAI of tree and grass was $0.72 \pm$ 0.13 and $0.36 \pm 0.12$, respectively. It is clear that the trees grown closer to each other (i.e., at $120 \mathrm{~mm}$ spacing) had less increase in LAI. This led to a final tree LAI of $1.3 \pm$ 0.11 , which was $15 \%-25 \%$ lower than that recorded in other wider spacings. This was likely because of the more significant tree-tree competition for soil moisture when tree spacing was closer. Also, close tree spacing caused overlaps of tree canopies, which led to the suppression of the growth of tree leaves underneath. There appeared to have no discernible difference of the tree LAI for the spacings of 180 and $240 \mathrm{~mm}$ because no overlap of tree canopies was observed in these two cases.

Tree spacing showed significant effects on the grass LAI. There was apparently no change in grass LAI when the tree spacing was close (i.e., $120 \mathrm{~mm}$ ). As a result of the overlaps of tree canopies, the grass underneath has been almost completely shaded from the sunlight, preventing the grass from receiving the solar radiation and hence 
suppressing its growth (Razados-Lorenzo et al. 2007). Such shading effects reduced as the tree spacing was wider, allowing more sunlight to reach the grass underneath for better growth (hence higher grass LAI).

Figure 4 shows the distributions of RAI of grass and tree with depth. It is clear that the RAI profiles of trees at any tree spacing exhibited a similar parabolic shape, all consistently peaked at around $90 \mathrm{~mm}$ depth. Increasing tree spacing from 120 to $240 \mathrm{~mm}$ resulted in $\sim 15 \%$ increase in root depth (Fig.4; Table 1). It appeared that the tree RAI in the top $110 \mathrm{~mm}$ was more substantially affected by tree spacing, whereas that below $110 \mathrm{~mm}$ depth were similar between the three cases. When the tree spacing was the closest at $120 \mathrm{~mm}$, the peak RAI was $14 \%-20 \%$ higher than that identified in other two wider spacing cases, despite of the smallest size of root volume (refer to Fig. 2(a)). This was because the significant tree-tree competition for close tree spacing might have activated the production of abscisic acid for tree root proliferation and survival (Munns and Sharp 1993), hence resulting in the substantial increase in RAI.

The RAI profiles of the grass were markedly different from those of the trees. The grass RAI reduced with depth almost linearly in the top $100 \mathrm{~mm}$ of the ground and the peak RAI was always found in the ground surface. The magnitude of grass RAI was strongly affected by the tree spacing, but in a way opposite from that on tree RAI. Peak RAI of grass increased by $29 \%$ as the tree spacing increased from 120 to $240 \mathrm{~mm}$. This demonstrated an evident interaction and growth pattern between the grass and tree. As the trees were grown further away from each other, the grass-tree competition reduced, hence encouraging the grass growth and leading to higher LAI 
(Fig. 3), higher RAI (Fig. 4) and deeper root depth (Fig. 4; Table 1).

\section{Measured saturated hydraulic conductivity}

Figure 5 shows the effects of tree spacing on the measured $k_{s}$ of the vegetated soils. The values of $k_{s}$ of the bare soil measured in the present study and that by Leung et al. (2015a), who adopted the Instantaneous Profile Method (Ng and Leung 2012) to measure the $k_{s}$ of the same soil type at the same dry density, were given for comparison. It is found that $k_{s}$ of vegetated soil can be higher or lower than that of the bare soil, depending on the tree spacing. There was a clear trend of reduction of $k_{s}$ as tree spacing increased. When the tree spacing was wider (i.e., 180 and $240 \mathrm{~mm}$ ), $k_{s}$ of the vegetated soil was lower than that of the bare soil. The same trend was found in the field tests reported by Rahardjo et al. (2014) and Leung et al. (2015a). Rahardjo et al. (2014) showed that the silty soil vegetated with either Jasmine or Vertier grass had a $k_{s}$ almost one order of magnitude lower than the bare soil. The vegetated sandy soil tested by Leung et al. (2015a) also had a lower $k_{s}$ than the bare soil, though by no more than $45 \%$. A plausible reason for the observed consistent trend is attributable to the blockage of soil pore space by roots (Buczko et al. 2007; Scanlan and Hinz 2010; Leung et al. 2015a; $\mathrm{Ng}$ et al. 2016b). Another possible reason is that the hydrophobic organic compounds released by roots, such as sugars, amino acids and phospholipids (Bengough 2012), may also decrease the $k_{s}$ observed in the vegetated ground. This is especially the case for tree spacings of 180 and $240 \mathrm{~mm}$ where decayed roots were less evident. 
In contrast, the measured $k_{s}$ of the vegetated soil at the spacing of $120 \mathrm{~mm}$ in the present study was evidently higher than that in the bare soil. The observed decay roots for spacing $120 \mathrm{~mm}$ (see Fig. 2) likely created preferential flow channels (Ghestem et al. 2011; Wu et al. 2016), hence causing an increased in soil hydraulic conductivity. This effect might have outweighed the effects of the blockage of soil pore space by plant roots or the release of hydrophobic organic compounds on the decrease in $k_{s}$. Some previous field studies (van Noordwijk et al. 1991; Mitchell et al. 1995; Vergani and Graf 2015) also showed higher infiltration rate in vegetated soils than in the bare soil. However, it must be emphasised that these previous studies focused on one single mature plant (i.e., not multiple plants like the present study). The observation found from the previous studies, although similar to what were identified in the present field study, was not because of the effects of plant spacing but was attributable to aging effects, which have also led to decayed roots and preferential water flow.

\section{Effects of tree spacing on ET-induced suction response}

Figure 6(a) compares the measured variations of suction of bare and vegetated grounds at $100 \mathrm{~mm}$ depth with time during the first stage of monitoring (i.e., under mixed grass-tree conditions). When compared to the bare ground, the suction induced in any vegetated ground was always higher, regardless of the tree spacing. This is expected because of additional removal of soil moisture through plant transpiration in the vegetated grounds, whereas only evaporation took place in the bare ground. Among the three vegetated grounds, the one with the closest tree spacing $(120 \mathrm{~mm})$ 
showed the greatest rate of suction increase and induced the highest amount of suction that peaked at $87 \mathrm{kPa}$. This may be because of the markedly higher RAI (hence higher root surface area for water uptake) of tree roots when trees were grown closer to each other (see Fig. 4). In this case, the root-water uptake by grass was likely to be minimal because of the significant suppression of grass growth when trees were grown closer to each other (see Figs 2(b), 3 and 4). A further increase in tree spacing to $180 \mathrm{~mm}$, however, resulted in a peak suction (57 kPa; see Fig. 6(a)) 16\% lower than the case with $240 \mathrm{~mm}$ spacing $(68 \mathrm{kPa})$, even though the tree RAI for $180 \mathrm{~mm}$ spacing was around 5\% higher. It must be emphasised that an increase in tree spacing led to an increase in grass RAI, unlike the case of trees that their RAI reduced. This means that as tree spacing increased, the effects of grass root-water uptake became more prominent, causing more significant influences on induced suction.

The measured suction responses of the bare and vegetated grounds during the second stage of monitoring (when grass was absent) are shown in Fig. 6(b). The suction induced by trees alone in this case was generally higher than those found in the mix-species condition. Plants use water mainly for metabolic processes, which have been found to be more evident when there is less inter-species competition for water (Qiu et al. 2011; Hölttä and Sperry 2012). This seems to imply that the tree would have a higher metabolic rate in the absence of grass, leading to demand of water and hence higher suction than those measured in the grass-tree condition. Similar findings are also supported by Hector et al. (2002) and Mazzacavallo and Kulmatiski (2015), who consistently showed that in mixed plantations, inter-species 
competition reduced the production of both species and also their root water uptake abilities. The higher suction observed in the second stage of monitoring could not be attributable to any increased water uptake ability due to tree growth. This is because the two monitoring periods were separated by less than 20 hours and any tree growth was minimal. The climate condition during the two periods was indiscernible, and thus could not be a major factor leading to the observed suction differences.

When comparing the suction responses among the three vegetated grounds, the peak induced suction increased with a decrease in tree spacing. Since the grass was absent in this case, the major contributing factor to the amount of induced suction should be related to tree RAI. It appeared that the higher the tree RAI, the higher the peak ET-induced suction would be. Such correlation was not found from the first monitoring period when grass existed (Fig. 6(a)). The comparison of the suction responses between the two periods highlights the significance of grass-tree interaction. Under mixed grass-tree conditions, trees having a wider spacing would reduce grass-tree competition and hence encourage the growth of grass roots (Figs 3 and 4). This would result in combined effects of grass and tree root-water uptake on induced suction.

\section{Effects of tree spacing on suction responses during rainfall}

Comparisons of the measured responses of suction between the bare and vegetated grounds at $100 \mathrm{~mm}$ depth during the first monitoring period (when grass existed) are shown in Fig. 6(a). After subject to the relatively intense rainfall with a peak intensity 
of $12 \mathrm{~mm} / \mathrm{hr}$, no suctions were preserved in both the bare and vegetated grounds, regardless of the spacing of trees. This implies that the different size of tree canopy as a result of the different tree spacing did not have significant interception effects on the suction response. However, it appeared that the closer the tree spacing, the greater rate and greater amount of suction drop would be. The vegetated ground with the closest spacing of $120 \mathrm{~mm}$ took 16 hours to reduce all the suction, whereas that with the wider spacings of 180 and $240 \mathrm{~mm}$ took 8 hours longer. There were two counteracting factors in affecting the suction responses, namely the initial ET-induced suction before rainfall and the vegetation effects on $k_{s}$. It has been experimentally demonstrated that for a given soil, the higher the initial suction before rainfall, the higher the suction preserved would be, due to the reduction of the soil hydraulic conductivity ( $\mathrm{Ng}$ et al. $2014,2015,2016 b, c, d)$. This is opposite to what is shown from the field data presented in the figure. Even though the suction induced by grass and tree ET for the case of $120 \mathrm{~mm}$ was the highest, the rate of suction drop was the greatest and the amount of suction preserved was the lowest. This is because the increase in $k_{s}$ due to closer tree spacing (see Fig. 5) was much more significant than the drop of unsaturated hydraulic conductivity due to ET-induced suction.

Figure 6(b) compares the suction response during rainfall after grass removal in the second stage of monitoring. As the rainfall intensity was smaller and the duration was shorter in this case, the suction drop was less significant than that recorded in the previous monitoring period (refer to Fig. 6(a)). As can be seen in Fig. 6(b), some suctions were preserved in all three vegetated grounds and they were consistently 
higher than those preserved in the bare ground, regardless of the tree spacing. It can be observed that the closer the tree spacing, the lower the suction preserved would be.

Figure 7 shows the vertical distribution of suction before and after 10 hours of rainfall (i.e., when the first rainfall event in the first monitoring period ended) with and without the presence of grass. Under mixed grass-tree conditions (Fig. 7(a)), suctions in the top $250 \mathrm{~mm}$ depth in all bare and vegetated grounds were affected by the rainfall, whereas the suctions at $450 \mathrm{~mm}$ depth apparently unchanged. Under this particular rainfall event, the presence of vegetation appeared to have negligible effects on the depth of influence zone of suction, which was consistently shallower than 450 $\mathrm{mm}$ depth in all four cases. At depths both within and below the root zone of trees, the magnitude of suction preserved was higher when tree spacing was wider. The same trend is found when the grass was absent (see Fig. 7(b)). This further suggests that the amount of ET-induced suction before the rainfall was comparatively less important for the suction responses during rainfall than the effects of tree spacing on the change in $k_{s}$ (Fig. 5). The laboratory study conducted by Leung et al. (2015b) also showed that the effects of vegetation on the change in soil hydraulic properties, including not only soil hydraulic conductivity but also soil water retention curve (SWRC), played a more significant role in the suction responses under rainfall, compared to the effects of ET. Recent studies (Scholl et al. 2014; Ng et al. 2016e) have demonstrated that the shape of a SWRC could change significantly with the volume of roots present in the soil.

$\mathrm{Ng}$ et al. (2016b), who also investigated the effects of tree spacing on suction responses but without grass, recommended that it is more beneficial to have closer 
tree spacing to preserve higher suction below the root zone of trees after rainfall. The present field study, however, did not share the same view because under mixed grass-tree conditions, the suction preserved both within and below the root zone of trees was the lowest when trees are closely spaced (Fig. 7(a)). Instead, it appeared to be more beneficial to have wider tree spacing to reduce grass-tree interaction, which would encourage grass growth (Figs 3 and 4), minimise the number of decayed roots (Fig. 2) and hence lead to the greater reduction in $k_{s}$ (Fig. 5).

\section{Discussion}

In order to improve the understanding of the effects of tree-grass interaction on the hydrological responses of soil, the peak ET-induced suction is related to tree RAI at $100 \mathrm{~mm}$ depth in Fig. 8. Regardless of the presence of grass, there appeared to have a positive linear correlation between the measured suction and tree RAI. Together with the test data reported by $\mathrm{Ng}$ et al. (2016b), who tested the same tree species grown in the same soil type as the present study, the correlation was highly significant (with p-value $<0.001)$. Tree RAI was thus an important below-ground trait that primarily governed the magnitude of ET-induced suction. In fact, RAI is a measure of the surface area of fine roots, which has already been demonstrated to govern the ability of plant root-water uptake (Jackson et al. 1997). Figure 9 shows that measured RAI of Schefflera heptaphylla appears to correlate with measurements of root biomass per soil volume reasonably well, with a p-value $<0.002$. This seems to indicate that one might use root biomass, which is a relatively common and easily measured root index 
than RAI, to correlate with matric suction.

During nutrient uptake, a change in ion concentration in the xylem would induce certain amount of osmotic suction in the plant. In general, herbaceous species (such as Cynodon dactylon investigated in this study) usually has lower osmotic suction than woody species (such as Schefflera heptaphylla) (Fereres et al. 1979). However, it should be noted that osmotic suction in plant is important only when the soil is fertile and when transpiration is not significant (e.g., during nighttime or high relative humidity condition; Tyree and Jarvis 1982; Taiz and Zeiger 2002). Since the CDG investigated in this study is infertile, any osmotic suction induced in the grass and tree species is expected not to be significant. Also because of the low nutrient content in the CDG, any change in osmotic suction in the soil due to change of salt concentration in water by nutrient uptake should be minimal (Schlesinger et al. 1996; Jobbagy and Jackson 2001).

Figure 10(a) relates the amount of suction preserved after 10 hours of rainfall with tree RAI at depth of $100 \mathrm{~mm}$. No correlation can be found in the present study, regardless of the presence of grasses, as well as the study carried out by $\mathrm{Ng}$ et al. (2016b). This appeared to be contradictory with the results reported by $\mathrm{Ng}$ et al. (2016a), who showed that for single species condition, there was a linear correlation between suction preserved and RAI. In an attempt to explain such contradiction, the suction preserved was related with $k_{s}$ in Fig. 10(b). Unfortunately, Ng et al. (2016b) did not report the values of $k_{s}$ in the vegetated ground. Thus, only the results obtained from this study were shown in Fig. 10(b). A significant correlation (p-value $<0.002$ ) 
can be found, showing a clear trend that the suction preserved reduced with an increase in $k_{s}$. This suggests that upon wetting, the effects of preferential water flow created by the decayed roots due to tree-tree or tree-grass interaction affected the suction preserved much more prominently than the effects of RAI. Since there was no plant-plant interaction for the single species case tested by $\mathrm{Ng}$ et al. (2016a), no significant preferential flow took place and this explains why RAI in their case was the predominant factor governing the suction preserved.

The field data shows that the increase in $k_{s}$ appeared to be significant only within the top $0.1 \mathrm{~m}$ depth of the root zone due to the presence of decayed roots for smaller tree spacing case. However, it should be noted that in slope situation, this kind of root-induced increase in $k_{s}$ or infiltration rate may not always necessarily jeopardize the slope stability. First of all, within the root zone, root cohesion contributed by mechanical reinforcement or/and hydrological effects of transpiration-induced suction might offset more than the effects of root-induced increase in infiltration rate (Simon and Collison 2002; Ghestem et al. 2011). Secondly, the root zone that contains decay roots may act as a sponge-like layer that could reduce erosive energy and improve slope stability, depending on slope angles (Sakals et al. 2006). Finally, in longer term from ecological perspective, the decay roots may turn into organic substance, contributing to plant nutrients and improving soil fertility for sustainable growth of tree. This would help maintain the nutrient cycle in soil and ecology (Ostertag and Hobbie 1999; Chen et al. 2001). In the future, the observed changes in $k_{s}$ or infiltration rate due to different plant spacing can be verified using in-situ double-ring 
infiltration tests (such as those conducted by Leung et al. (2015a)), which might give a better indication than tests on small laboratory samples obtained from cores.

\section{Conclusions}

This study presents and interprets a set of field monitoring data concerning on the effects of grass-tree interaction on plant growth and induced matric suction under different tree spacings (i.e., 120, 180 and $240 \mathrm{~mm}$ ). Plant traits including LAI and RAI (for fine roots with diameter $>2 \mathrm{~mm}$ ) and saturated hydraulic conductivity $\left(k_{s}\right)$ were measured to help interpret the observed matric suction responses upon ET and rainfall.

In terms of plant growth, a decrease in tree spacing from 240 to $120 \mathrm{~mm}$ led to a decrease in the size of root volume of trees by $30 \%$, but the peak tree RAI increased by $20 \%$. Closer tree spacing increased the grass-tree interaction and the overlaps of tree canopies shaded sunlight received by the grass underneath. This discouraged grass growth, resulting in $23 \%$ reduction in grass RAI and $45 \%$ shorter root length. When the trees were spaced closely at $120 \mathrm{~mm}$, decay of the roots of both grass and tree was identified. This has led to a significant increase in $k_{s}$, as compared to that in bare soil. In contrast, for the cases of wider tree spacings of 180 and $240 \mathrm{~mm}$ (where grass-tree interaction was less intense and fewer decayed roots were found), the presence of roots caused a reduction of $k_{s}$.

Trees closely spaced at $120 \mathrm{~mm}$ always induced the highest peak matric suction upon ET due to significant tree-tree or/and tree-grass interaction. Without grass, the 
peak ET-induced matric suction increased with a decrease in tree spacing. With mixed planting, however, opposite trend was observed for spacing 180 and $240 \mathrm{~mm}$. This is because of the better grass growth (hence higher grass RAI) as the trees were wider spaced. Root-water uptake from grasses became more prominent, hence leading to an increased ET-induced matric suction. Nevertheless, regardless of the presence of grasses and tree spacing, the peak ET-induced matric suction has a linear correlation with RAI.

Upon rainfall infiltration, it appeared to be more beneficial to plant grass and trees with wider spacing (i.e., $240 \mathrm{~mm}$ ) because higher amount of matric suction could be preserved. It is crucial to reveal that matric suction preserved after rainfall did not necessarily to be higher, even though the matric suction induced by close tree spacing cases before rainfall was higher. It is also important to identify that under mixed grass-tree condition, the matric suction preserved has no correlation with RAI, as was however identified for individual tree case. This is because the effects of the changes in $k_{s}$ under different degrees of tree-grass interaction were likely to control the ability of soil to preserve matric suction, as compared to effects of RAI.

\section{Acknowledgements}

We acknowledge research grant 2012CB719805 from the National Basic Research Program (973 Program) administered by the Ministry of Science and Technology of the People's Republic of China and research grants HKUST6/CRF/12R awarded by the Research Grants Council of the Government of the Hong Kong SAR. The second 
author acknowledges the EU Marie Curie Career Integration Grant under the project

'BioEPIC slope' and research travel support from the Northern Research Partnership (NRP).

\section{References}

ASTM. 2010a. Standard practice for classification of soils for engineering purposes (Unified Soil Classification System). ASTM standard D2487. American Society for Testing and Materials, West Conshohocken, Pa.

ASTM D5084 2010b. Standard test methods for measurement of hydraulic conductivity of saturated porous materials using a flexible wall permeameter. West Conshohocken, PA.

Azam-Ali, S. N., Gregory, P. J., and Monteith, J. L. 1984. Effects of planting density on water use and productivity of pearl millet (Pennisetum Typhoides) grown on stored water: Growth of roots and shoots. Experimental Agriculture, 20(3): 203214.

Bengough, A. G. 2012. Water dynamics of the root zone: rhizosphere biophysics and its control on soil hydrology. Vadose Zone Journal. 11(2). doi: 10.2136/vzj 2011.0111.

Benomar, L., DesRochers, A., and Larocque, G. 2012. The effects of spacing on growth, morphology and biomass production and allocation in two hybrid poplar clones growing in the boreal region of Canada. Trees - Structure and Function, 26(3): 939-949.

Buczko, U., Bens, O., and Hüttl, R. F. 2007. Changes in soil water repellency in a 
pine-beech forest transformation chronosequence: influence of antecedent rainfall and air temperatures. Ecological Engineering, 31(3): 154-164.

Chen, H., Harmon, M. E., and Griffiths, R. P. 2001. Decomposition and nitrogen release from decomposition woody roots in coniferous forests of the Pacific Northwest: chronosequence approach. Canadian Journal of Forest Research, 31(2): 246-260.

Chotte, J. L., Laurent, J. Y., and Rossi, J. P. 1995. A modified hydropneumo-elutriation apparatus for quantitative root separation from large soil core samples. Communications in Soil Science and Plant Analysis, 26(15\&16): $2703-2709$

Buhrke, V. E., Jenkins, R., and Smith, D. K. 1998. A Practical Guide for the Preparation of Specimens for XRF and XRD Analysis, Wiley, ISBN 0-471-19458-1.

Darawsheh, M. K., Khah, E. M., Aivalakis, G., Chachalis, D., and Sallaku, F. 2009. Cotton row spacing and plant density cropping systems I. Effects on accumulation and partitioning of dry mass and LAI. Journal of Food, Agriculture and Environment, 7(3-4): 258-261.

Eastham, J., Rose, C. W., Charles-Edwards, D. A., Cameron, D. M., and Rance, S. J. 1990. Planting density effects on water use efficiency of trees and pasture in an agroforestry experiment. New Zealand Journal of Forestry Science, 20(5): 39-53.

Farnham, D. E. 2001. Row spacing, plant density, and hybrid effects on corn grain yield and moisture. Agronomy Journal, 93(5): 1049-1053. 
Fereres, E., Cruz-Romero, G., Hoffman, G. J., and Rawlins, S. L. 1979. Recovery of orange trees following severe water stress. Journal of Applied Ecology, 16(3): $833-842$.

Francour, P., and Semroud, R. 1992. Calculation for the root area index in Posidonia oceanica in the Western Mediterranean. Aquatic Botany, 42(3): 281-286.

Fredlund, D. G., and Wong, D. K. 1989. Calibration of thermal conductivity sensors for measuring soil suction. Geotechnical Testing Journal, 12(3): 188-194.

Garg, A., Coo, J. L., and Ng, C. W. W. 2015a. Field study on influence of root characteristics on suction distributions in slopes vegetated with Cynodon dactylon and Schefflera heptaphylla. Earth Surface Processes and Landforms, 40(12): $1631-1643$.

Garg, A., Leung, A. K., and Ng, C. W. W. 2015b. Comparisons of soil suction induced by evapotranspiration and transpiration of S. heptaphylla. Canadian Geotechnical Journal, 52(12): 2149-2155.

GEO. 2011. Technical guidelines on landscape treatment for slopes. Geotechnical Engineering Office (GEO), Civil Engineering and Development Department, The Government of the Hong Kong Special Administrative Region.

Ghestem, M., Sidle, R. C., and Stokes, A. 2011. The influence of plant root systems on subsurface flow: implications for slope stability. Bioscience, 61(11): $869-879$.

Goldberg, D. E., and Miller, T. E. 1990. Effects of different resource additions on species diversity in an annual plant community. Ecology, 71(1): 213-225.

Green, D. S., Kruger, E. L., Stanosz, G. R., and Isebrands, J. G. 2001. Light-use 
efficiency of native and hybrid poplar genotypes at high levels of intracanopy competition. Canadian Journal of Forest Research, 31(6): 1030-1037.

Grouzis, M., and Akpo, L-E. 1997. Influence of tree cover on herbaceous above- and below-ground phytomass in the Sahelian zone of Senegal. Journal of Arid Environments, 35(2): 285-296.

Hau, B. C. H., and Corlett, R. T. 2003. Factors affecting the early survival and growth of native tree seedlings planted on a degraded hillside grassland in Hong Kong, China. Restoration Ecology, 11(4): 483-488.

Hector, A., Bazeley-White, E., Loreau, M., Otway, S., and Schmid, B. 2002. Overyielding in grassland communities: testing the sampling effect hypothesis with replicated biodiversity experiments. Ecology Letters, 5(4), 502-511.

Hölttä, T., and Sperry, J. 2012. Plant water transport and cavitation. Proceedings of the NATO Advanced Research Workshop on Alternative Water Resources in Arid Area by Retrieving Water from Secondary Sources, Ein Bokek, Israel, pp. $173-181$

Jackson, R. B., Mooney, H. A., and Schulze, E. D. 1997. A global budget for fine root biomass, surface area, and nutrient contents. Proceedings of the National Academy of Sciences, 94:7362-7366.

Jobbagy, E. G., and Jackson, R. B. 2001. The distribution of soil nutrients with depth: Golobal patterns and the imprint of plants. Biogeochemistry, 53(1): 51-77.

Leung, A. K. and Ng, C. W. W. 2013. Seasonal movement and groundwater flow mechanism in an unsaturated saprolitic hillslope. Landslides, 10(4): 455 - 467. 
Leung, A. K., Garg, A., Coo, J. L., Ng, C. W. W., and Hau, B. C. H. 2015a. Effects of the roots of Cynodon dactylon and Shefflera heptaphylla on water infiltration rate and soil hydraulic conductivity. Hydrological processes, 29(15): 3342-3354.

Leung, A. K., Garg, A., and Ng, C. W. W. 2015b. Effects of plant roots on soil-water retention and induced suction in vegetated soil. Engineering Geology, 193: 183197.

López, B., Sabaté, S., and Gracia, C.A. 2001. Vertical distribution of fine root density, length density, area index and mean diameter in a Quercus ilex forest. Tree Physiology, 21(8): 555-560.

Ludwig, F., de Kroon, H., Berendse, F., and Prins, H. H. T. 2004. The influence of savanna trees on nutrient, water and light availability and the understorey vegetation. Plant Ecology, 170(1): 93-105.

Mazzacavallo, M.G., and Kulmatiski, A. 2015. Modelling water uptake provides a new perspective on grass and tree coexistence. PLoS One, 10(12):e0144300.

Mitchell, A. R., Ellsworth, T. R., and Meek, B. D. 1995. Effect of root systems on preferential flow in swelling soil. Communications in Soil Science and Plant Analysis, 26(15-16): 2655-2666.

Munns, R., and Sharp, R. E. 1993. Involvement of abscisic acid in controlling plant growth in soil of low water potential. Australian Journal of Plant Physiology, 20(5): $425-437$.

Ng, C. W. W., and Leung, A. K. 2012. Measurements of drying and wetting permeability functions using a new stress-controllable soil column. Journal of 
Geotechnical and Geoenvironmental Engineering, 138(1): 58-68.

Ng, C. W. W., Leung, A. K., and Woon, K. X. 2014. Effects of soil density on grass-induced suction distributions in compacted soil subjected to rainfall. Canadian Geotechnical Journal, 51(3): 311-321.

Ng, C. W. W., and Menzies, B. 2007. Advanced unsaturated soil mechanics and engineering. London: Taylor \& Francis. ISBN: 9780415436793

Ng, C. W. W., Garg, A., Leung, A. K., and Hau, B. C. H. 2016a. Relationships between leaf and root area indices and soil suction induced during drying-wetting cycles. Ecological Engineering, 91: 113-118.

Ng, C.W.W., Ni, J. J., Leung, A. K., Zhou, C., and Wang, Z. J. 2016b. Effects of planting density on tree growth and induced soil suction. Géotechnique, doi: 10.1680/jgeot.15.P.196. In press.

Ng, C. W. W., Kamchoom, V., and Leung, A. K. 2016c. Centrifuge modelling of the effects of root geometry on transpiration-induced suction and stability of vegetated slopes. Landslide, doi: 10.1007/s10346-015-0645-7. In press.

Ng, C. W. W., Leung, A. K.,. Yu, R., and Kamchoom, V. 2016d. Hydrological effects of live poles on transient seepage in an unsaturated soil slope: Centrifuge and numerical study. Journal of Geotechnical and Geoenvironmental Engineering, ASCE. In press.

Ng, C. W. W., Ni, J. J., Leung, A. K., and Wang, Z. J. 2016e. A new and simple water retention model for root-permeated soils. Géotechnique Letters, 6(1): $106-111$. doi: 10.1680/jgele.15.00187. 
Ng, C. W. W., Woon, K. X., Leung, A. K., and Chu, L.M. 2013. Experimental investigation of induced suction distribution in a grass-covered soil. Ecological Engineering. 52: 219-223. doi: 10.1016/j.ecoleng.2012.11.013.

Ostertag, R., and Hobbie, S. E. 1999. Early stages of root and leaf decomposition in Hawaiian forests: effects of nutrient availability. Oecologia, 121(4): 564-573.

Pollen-Bankhead, N., and Simon, A. 2010. Hydrologic and hydraulic effects of riparian root networks on streambank stability: is mechanical root-reinforcement the whole story. Geomorphology, 116(3-4):353-362.

Qiu, Z. C., Wang, M., Lai, W. L., He, F. H., and Chen, Z. H. 2011. Plant growth and nutrient removal in constructed monoculture and mixed wetlands related to stubble attributes. Hydrobiologia, 661(1): 251-260.

Rahardjo, H., Satyanaga, A., Leong, E. C., Santoso, V. A., and Ng, Y. S. 2014. Performance of an instrumented slope covered with shrubs and deep-rooted grass. Soils and Foundations, 54(3): 417-425.

Rasband, W. S. 2011. Image J. Bethesda, MD, USA: US National Institutes of Health.

Reubens, B. 2010. Woody vegetation for gully rehabilitation in northern Ethiopia: species suitability, root structure, and seedling establishment, growth and management. PhD Dissertation, Katholieke Universiteit Leuven, Belgium

Rozados-Lorenzo, M. J., Gonza'lez-Herna'dez, M. P., and Silva-Pando, F. J. 2007. Pasture production under different tree species and densities in an Atlantic silvopastoral system. Agroforestry Systems, 70(1): 53-62.

Sakals, M., Innes, J. L., Wilford, D. J., Didle, R.C., and Grant G. E. 2006. The role of 
forests in reducing hydrogeomorphic hazards. Forest Snow and Landscape Research. 80(1), 11-22

Scanlan, C. A., and Hinz, C. 2010. Insight into the processes and effects of root induced changes to soil hydraulic properties. In 19th world congress of soil science, soil solutions for a changing world, Brisbane, Australia (eds R. Gilkes and N. Prakongkep), pp. 41-44 (CD-ROM).

Schade, J. D., Sponseller, R., Collins, S. L., and Stiles, A. 2003. The influence of Prosopsis canopies on understorey vegetation: Effects of landscape position. Journal of Vegetation Science, 14(5): 743-750.

Schlesinger, W. H., Raikes, J. A, Hartley, A. E., and Cross, A. F. 1996. On the spatial pattern of soil nutrients in desert ecosystems. Ecology, 77(2): 364-374.

Scholes, R. J., and Archer, S. R. 1997. Tree-grass interactions in savannas. Annual Review of Ecology and Systematics, 28: 517-544.

Scholl, P., Leitner, D., Kammerer, G., Lioskandl, W., Kaul, H. P., and Bodner, G. 2014. Root induced changes of effective 1D hydraulic properties in a soil column. Plant and Soil, 381(1-2): 193-213.

Simon, A., and Collison, A. J. C. 2002. Quantifying the mechanical and hydrologic effects of riparian vegetation on streambank stability. Earth Surface Processes and Landforms, 27(5): 527-546.

Smethurst, J. A., Briggs, K. M., Powrie, W., Ridley, A, and Butcher, D. J. E. 2015. Mechanical and hydrological impacts of tree removal on a clay fill railway embankment. Géotechnique, 65(11): 869-882. 
Smucker, A. J. M., McBurney, S. L., and Srivastava, A. K. 1982. Quantitative separation of roots from compacted soil profiles by the hydropneumatic elutriation system. Agronomy Journal, 74(3): 500-503.

Sparks, D. L., Page, A. L., Dalton, P. A, Loeppert, R. H, Soltanpour, P. N., Tabata, M. A., and Johnston, C. T. 1996. Methods of Soil Analysis: Part 3, Chemical Methods. Soil Science Society of America, American Society of Agronomy, Madison.

Taiz, L., and Zeiger, E. 2002. Plant Physiology. Sinauer Associates, third Edition.

Tyree, M. T., and Jarvis, P. G. 1982. Water in tissues and cells. Physiological plant ecology II. Springer Berlin Heidelberg, 35-77.

van Noordwijk, M., Widianto, H. M., and Hairah, K. 1991. Old tree root channels in acid soils in the humid tropics: Important for crop root penetration, water infiltration and nitrogen management. Developments in Plant and Soil Sciences, 134(1): $37-44$.

Vergani, C., and Graf, F. 2015. Soil permeability, aggregate stability and root growth: a pot experiment from a soil bioengineering perspective. Ecohydrology, doi: 10 . 1002/eco. 1686.

Wang, D., Kang, Y., and Wan, S. 2007. Effect of soil matric potential on tomato yield and water use under drip irrigation condition. Agricultural Water Management, 87(2): 180-186.

Wu, G. L., Yang, Z., Cui, Z., Liu, Y., Fang, N. F., and Shi, Z. H. 2016. Mixed artificial grasslands with more roots improved mine soil infiltration capacity. Journal of Hydrology. 535: $54-60$. 


\section{Figure Captions}

Fig. 1. Test setup and instrumentation

Fig. 2. (a) Overview of some root systems of (a) trees and (b) grasses at different tree spacing (Each grid represents a $10 \mathrm{~mm} * 10 \mathrm{~mm}$ square)

Fig. 3. Measured changes in LAI of trees and grasses during the growing period

Fig. 4. Measured profiles of RAI of trees and grasses after 4-month growing period

Fig. 5. Effects of plant spacing on saturated hydraulic conductivity of soil

Fig. 6. Measured variations of matric suction at depth $100 \mathrm{~mm}$ with time (a) with and

(b) without grass

Fig. 7. Measured vertical distributions of matric suction along depth during rainfall (a) with and (b) without grass

Fig. 8. Correlations between tree RAI and peak ET-induced matric suction at depth $100 \mathrm{~mm}$

Fig. 9. Correlation between RAI and root biomass per soil volume. Error bars refer to standard error (sample number $=3$ ) (raw data from Garg et al. $(2015 b)$ and Leung et al., (2015b))

Fig. 10. (a) Correlations of matric suction preserved after 10 hours of rainfall at depth $100 \mathrm{~mm}$ with (a) tree RAI; and (b) ks 


\section{Table 1. Summary of some traits of tree and grass}

\begin{tabular}{|c|c|c|c|c|c|c|c|}
\hline & \multirow{2}{*}{ Plant traits } & \multicolumn{2}{|c|}{ Spacing $120 \mathrm{~mm}$} & \multicolumn{2}{|c|}{ Spacing $180 \mathrm{~mm}$} & \multicolumn{2}{|c|}{ Spacing $240 \mathrm{~mm}$} \\
\hline & & Tree & Grass & Tree & Grass & Tree & Grass \\
\hline \multirow{3}{*}{ 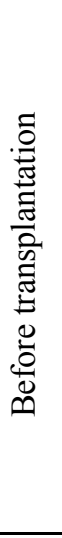 } & $\begin{array}{l}\text { Shoot height: } \\
\text { mm }\end{array}$ & $\begin{array}{l}562-640 \\
\text { Mean: } 601 \\
\text { S.D. : } \pm 38\end{array}$ & $\begin{array}{c}14-32 \\
\text { Mean: } 24 \\
\text { S.D. : } \pm 8\end{array}$ & $\begin{array}{c}568-625 \\
\text { Mean: } 596 \\
\text { S.D. : } \pm 26\end{array}$ & $\begin{array}{c}15-36 \\
\text { Mean: } 26 \\
\text { S.D. : } \pm 9\end{array}$ & $\begin{array}{c}572-632 \\
\text { Mean: } 604 \\
\text { S.D. : } \pm 27\end{array}$ & $\begin{array}{c}12-37 \\
\text { Mean: } 24 \\
\text { S.D. : } \pm 12\end{array}$ \\
\hline & $\begin{array}{c}\text { Leaf area } \\
\text { index (LAI) }\end{array}$ & $\begin{array}{c}0.58-0.95 \\
\text { Mean: } 0.73 \\
\text { S.D. : } \pm 0.13\end{array}$ & $\begin{array}{c}0.28-0.42 \\
\text { Mean: } 0.35 \\
\text { S.D. : } \pm 0.05\end{array}$ & $\begin{array}{c}0.65-0.81 \\
\text { Mean: } 0.75 \\
\text { S.D. : } \pm 0.06\end{array}$ & $\begin{array}{c}0.25-0.51 \\
\text { Mean: } 0.37 \\
\text { S.D. : } \pm 0.12\end{array}$ & $\begin{array}{c}0.58-0.79 \\
\text { Mean: } 0.70 \\
\text { S.D. : } 0.08\end{array}$ & $\begin{array}{c}0.27-0.44 \\
\text { Mean: } 0.36 \\
\text { S.D. :0.07 }\end{array}$ \\
\hline & $\begin{array}{l}\text { Root depth: } \\
\text { mm }\end{array}$ & $\begin{array}{c}100-134 \\
\text { Mean: } 116 \\
\text { S.D. : } \pm 18\end{array}$ & $\begin{array}{c}21-40 \\
\text { Mean: } 32 \\
\text { S.D. : } \pm 10\end{array}$ & $\begin{array}{c}98-140 \\
\text { Mean: } 121 \\
\text { S.D. : } \pm 21\end{array}$ & $\begin{array}{c}20-43 \\
\text { Mean:29 } \\
\text { S.D. : } \pm 11\end{array}$ & $\begin{array}{c}101-129 \\
\text { Mean: } 113 \\
\text { S.D. : } \pm 13\end{array}$ & $\begin{array}{c}20-45 \\
\text { Mean: } 33 \\
\text { S.D. : } \pm 12\end{array}$ \\
\hline \multirow{3}{*}{ 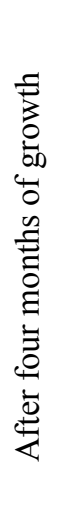 } & $\begin{array}{l}\text { Shoot height: } \\
\text { mm }\end{array}$ & $\begin{array}{c}679-734 \\
\text { Mean: } 708 \\
\text { S.D. : } \pm 27 \\
\end{array}$ & $\begin{array}{c}41-68 \\
\text { Mean: } 56 \\
\text { S.D. : } \pm 13 \\
\end{array}$ & $\begin{array}{c}675-748 \\
\text { Mean: } 715 \\
\text { S.D. : } \pm 35\end{array}$ & $\begin{array}{c}65-93 \\
\text { Mean: } 79 \\
\text { S.D. : } \pm 14\end{array}$ & $\begin{array}{c}583-742 \\
\text { Mean: } 711 \\
\text { S.D. : } \pm 30 \\
\end{array}$ & $\begin{array}{c}90-121 \\
\text { Mean: } 108 \\
\text { S.D. : } \pm 16\end{array}$ \\
\hline & $\begin{array}{c}\text { Leaf area } \\
\text { index (LAI) }\end{array}$ & $\begin{array}{c}1.20-1.43 \\
\text { Mean: } 1.30 \\
\text { S.D. }: \pm 0.11\end{array}$ & $\begin{array}{c}0.23-0.46 \\
\text { Mean: } 0.36 \\
\text { S.D. : } \pm 0.09\end{array}$ & $\begin{array}{c}1.46-1.64 \\
\text { Mean: } 1.54 \\
\text { S.D. : } \pm 0.07\end{array}$ & $\begin{array}{c}0.58-0.79 \\
\text { Mean: } 0.67 \\
\text { S.D. : } \pm 0.10\end{array}$ & $\begin{array}{c}1.48-1.72 \\
\text { Mean: } 1.63 \\
\text { S.D. : } \pm 0.09\end{array}$ & $\begin{array}{c}0.78-0.99 \\
\text { Mean: } 0.89 \\
\text { S.D. : } \pm 0.09\end{array}$ \\
\hline & $\begin{array}{l}\text { Root depth: } \\
\qquad \mathrm{mm}\end{array}$ & $\begin{array}{c}145-192 \\
\text { Mean: } 171 \\
\text { S.D. : } \pm 23\end{array}$ & $\begin{array}{c}\text { 43-61 } \\
\text { Mean: } 52 \\
\text { S.D. : } \pm 8\end{array}$ & $\begin{array}{c}168-204 \\
\text { Mean: } 186 \\
\text { S.D. : } \pm 16\end{array}$ & $\begin{array}{c}61-80 \\
\text { Mean: } 72 \\
\text { S.D. : } \pm 9\end{array}$ & $\begin{array}{c}177-216 \\
\text { Mean: } 198 \\
\text { S.D. : } \pm 19\end{array}$ & $\begin{array}{c}\text { 81-108 } \\
\text { Mean: } 96 \\
\text { S.D. : } \pm 14\end{array}$ \\
\hline
\end{tabular}




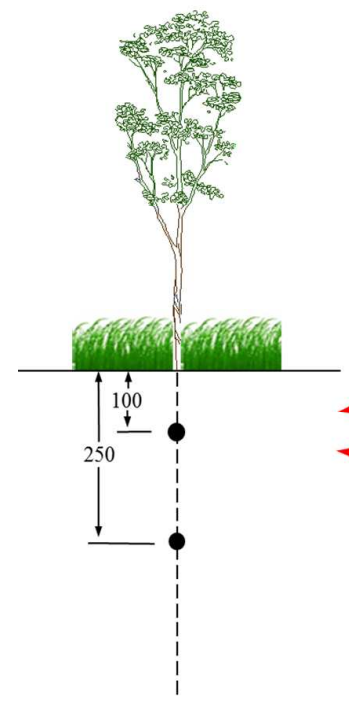

Section view (II, III)

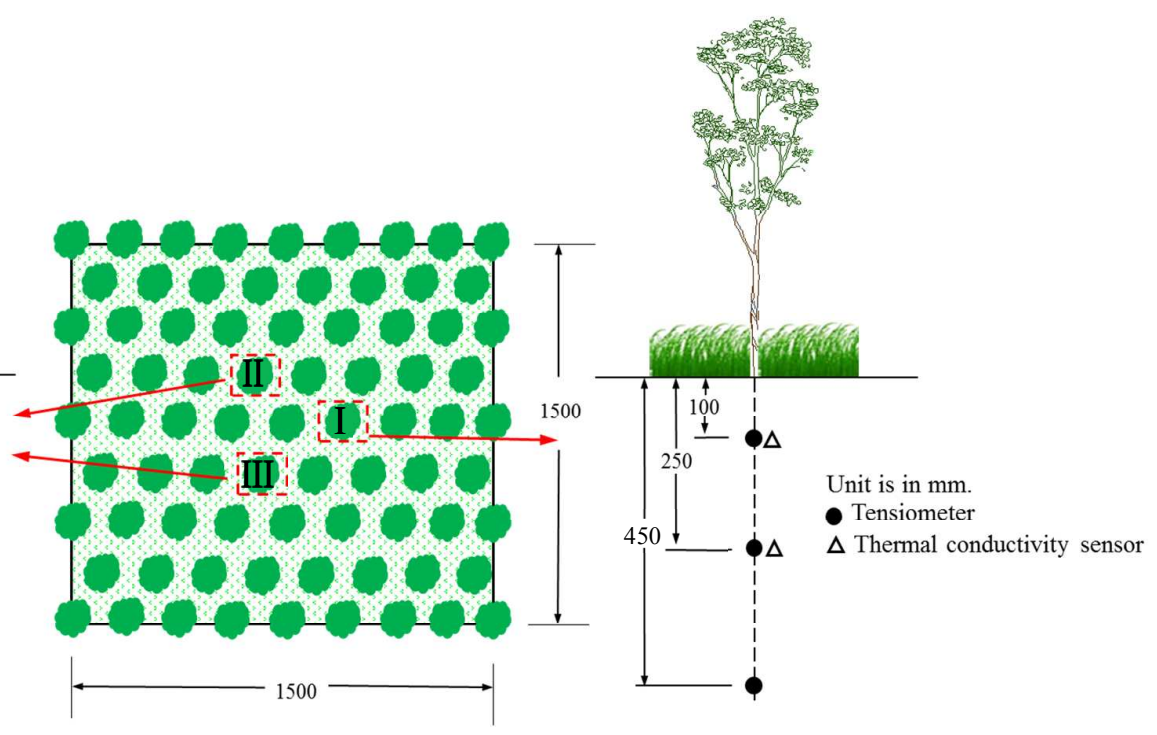

Plan view
Section view (I)

Fig. 1. Test setup and instrumentation 


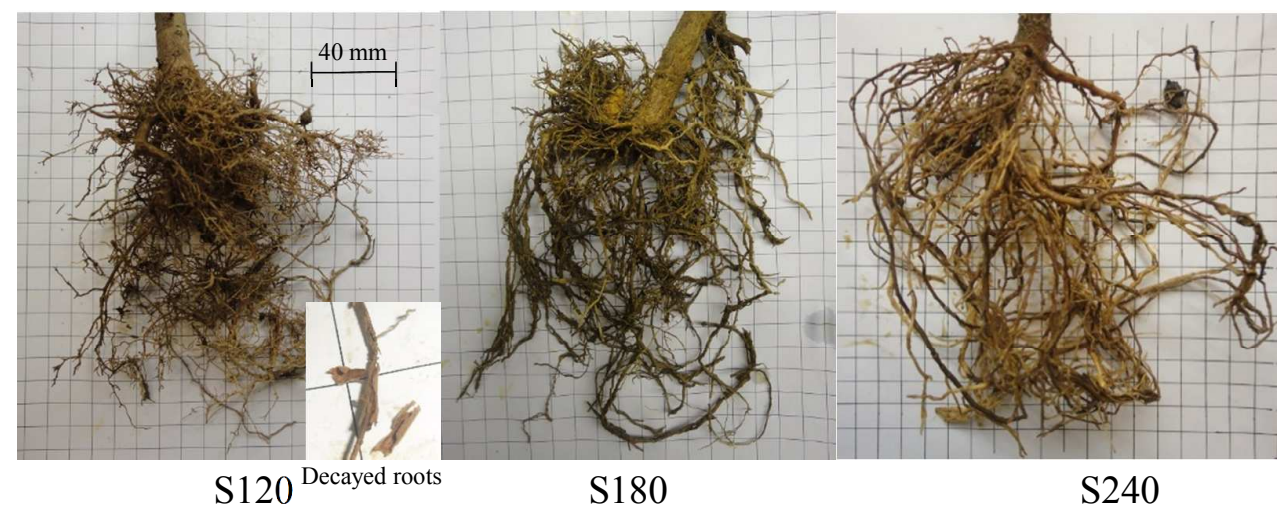

(a)

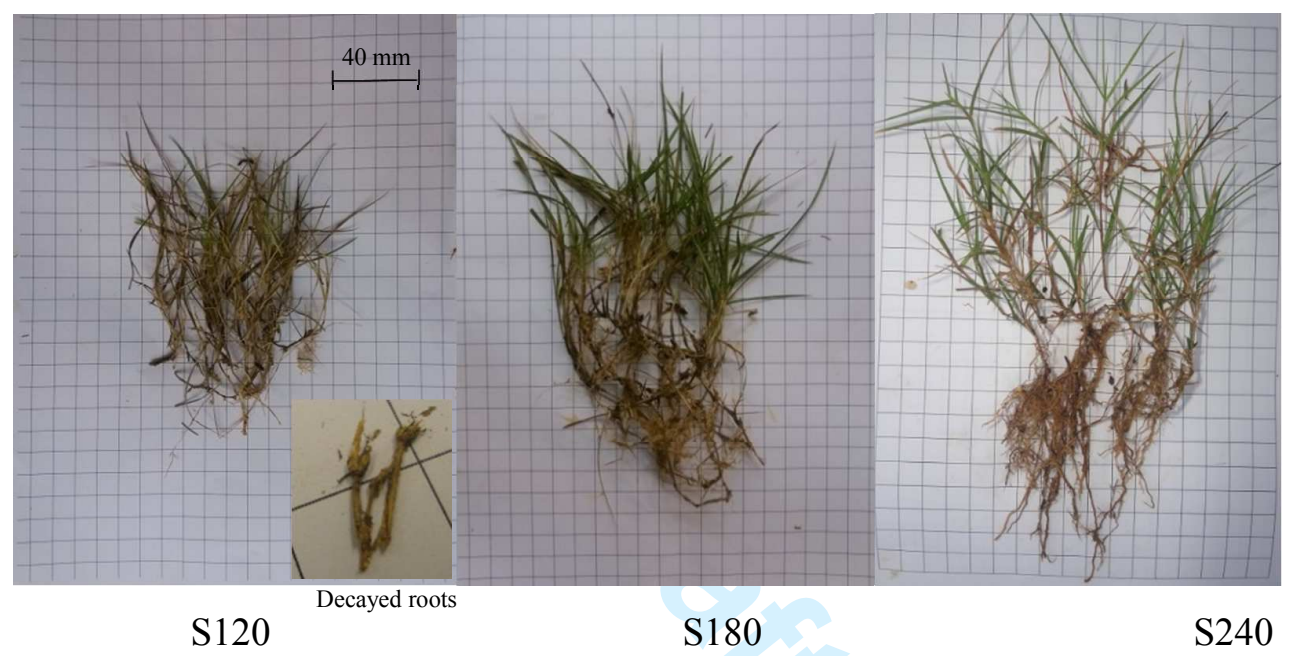

(b)

Fig. 2. (a) Overview of some root systems of (a) trees and (b) grasses at different tree spacing (Each grid represents a $10 \mathrm{~mm} * 10 \mathrm{~mm}$ square) 


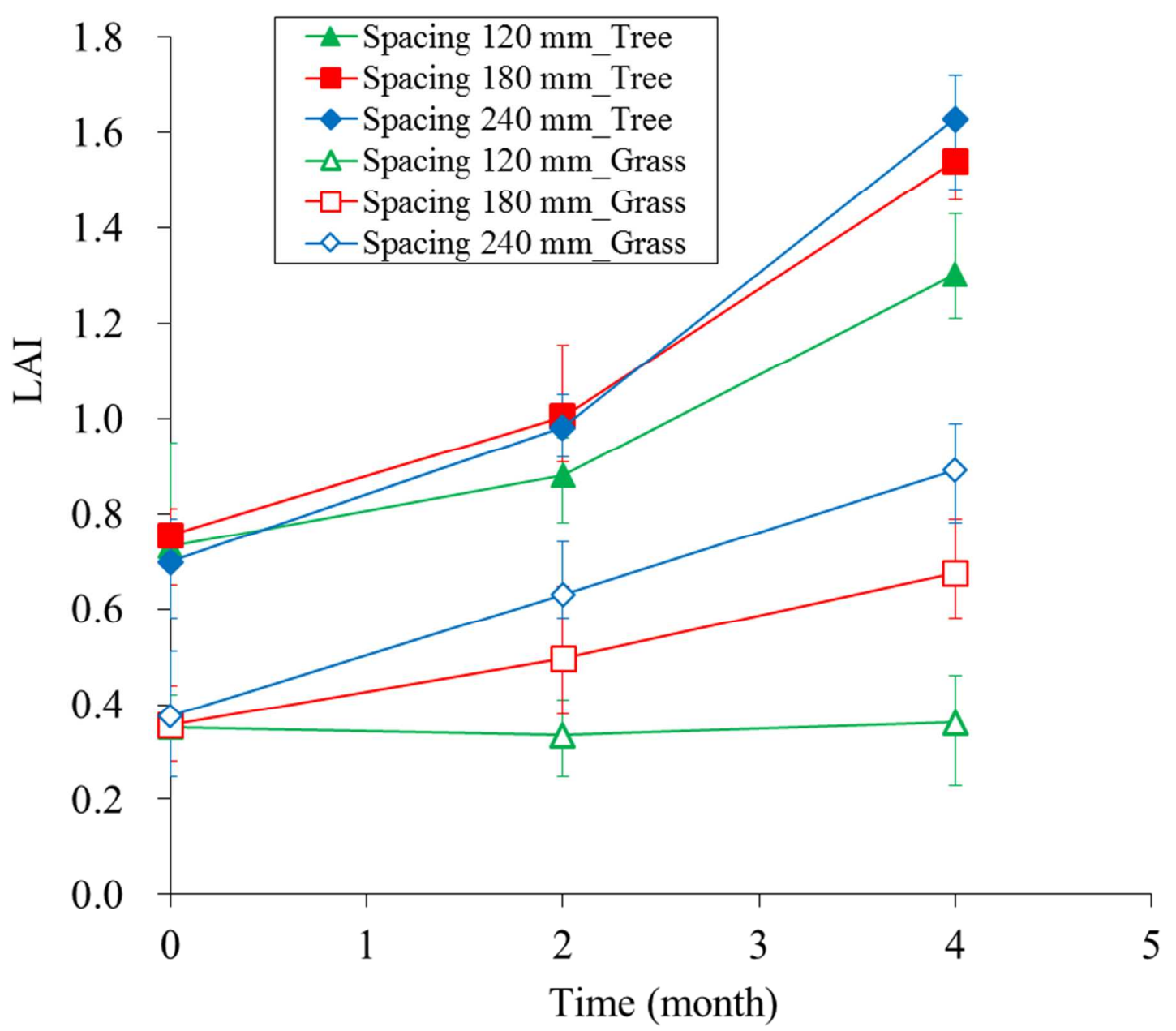

Fig. 3. Measured changes in LAI of trees and grasses during the growing period 


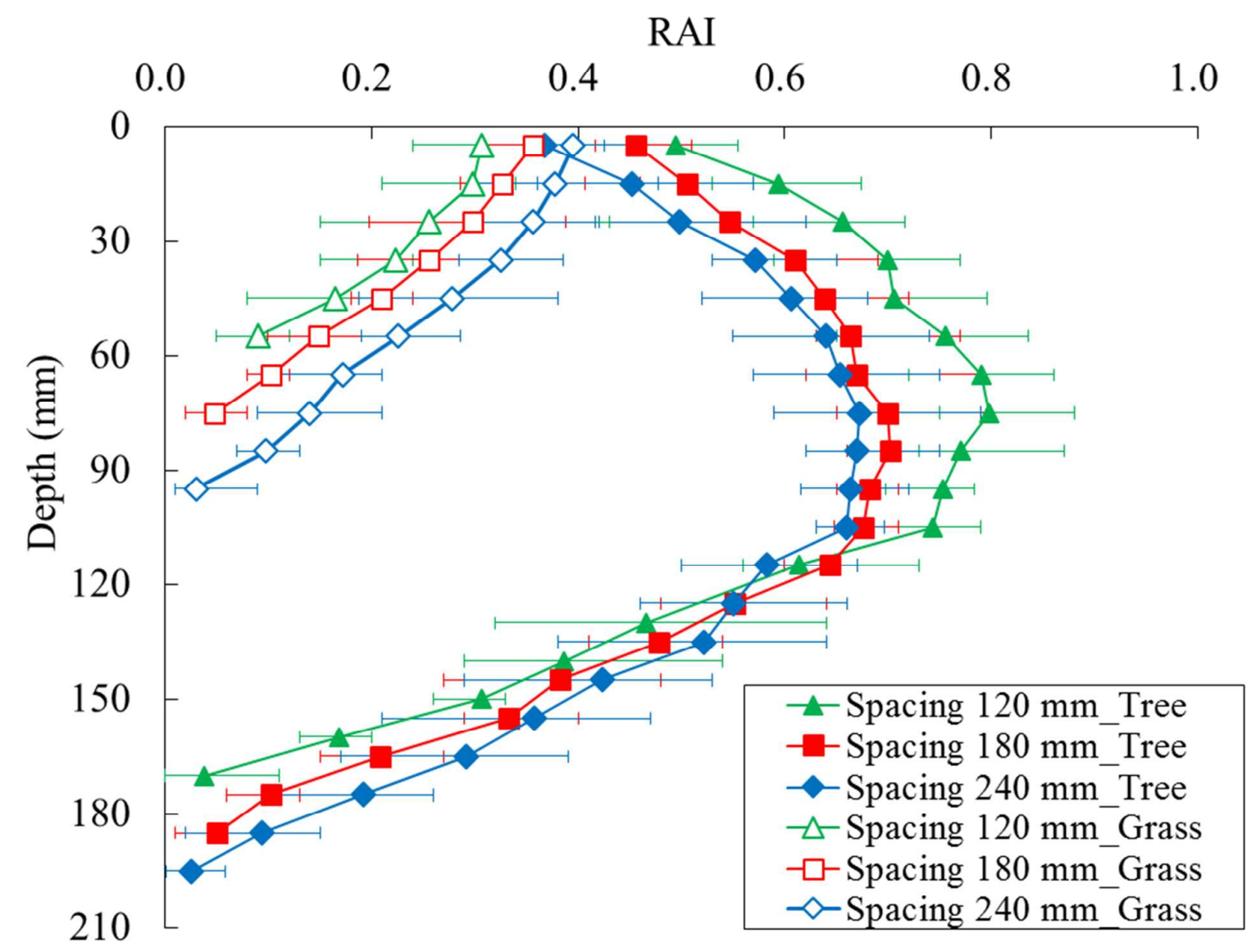

Fig. 4. Measured profiles of RAI of trees and grasses after 4-month growing period 


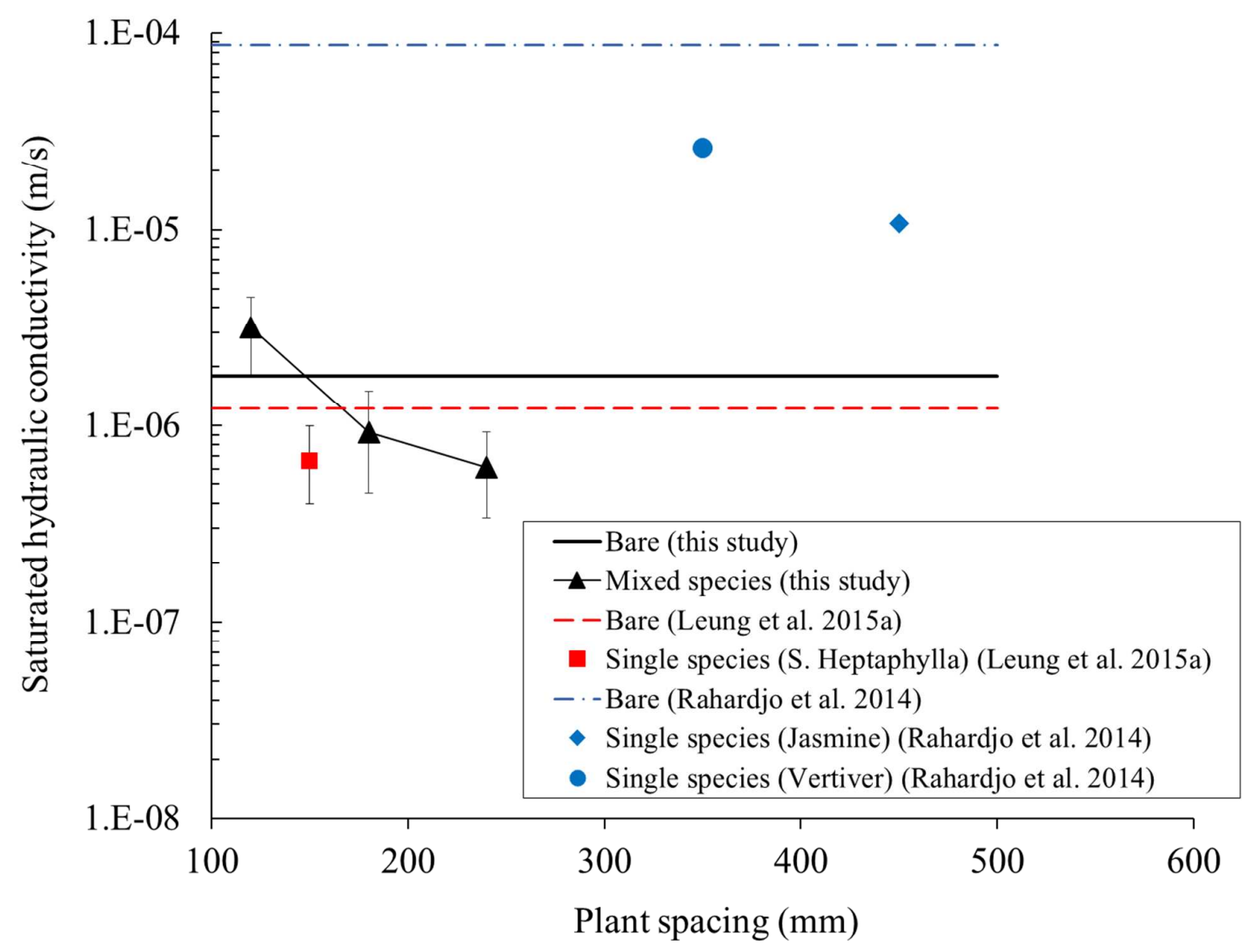

Fig. 5. Effects of plant spacing on saturated hydraulic conductivity of soil 


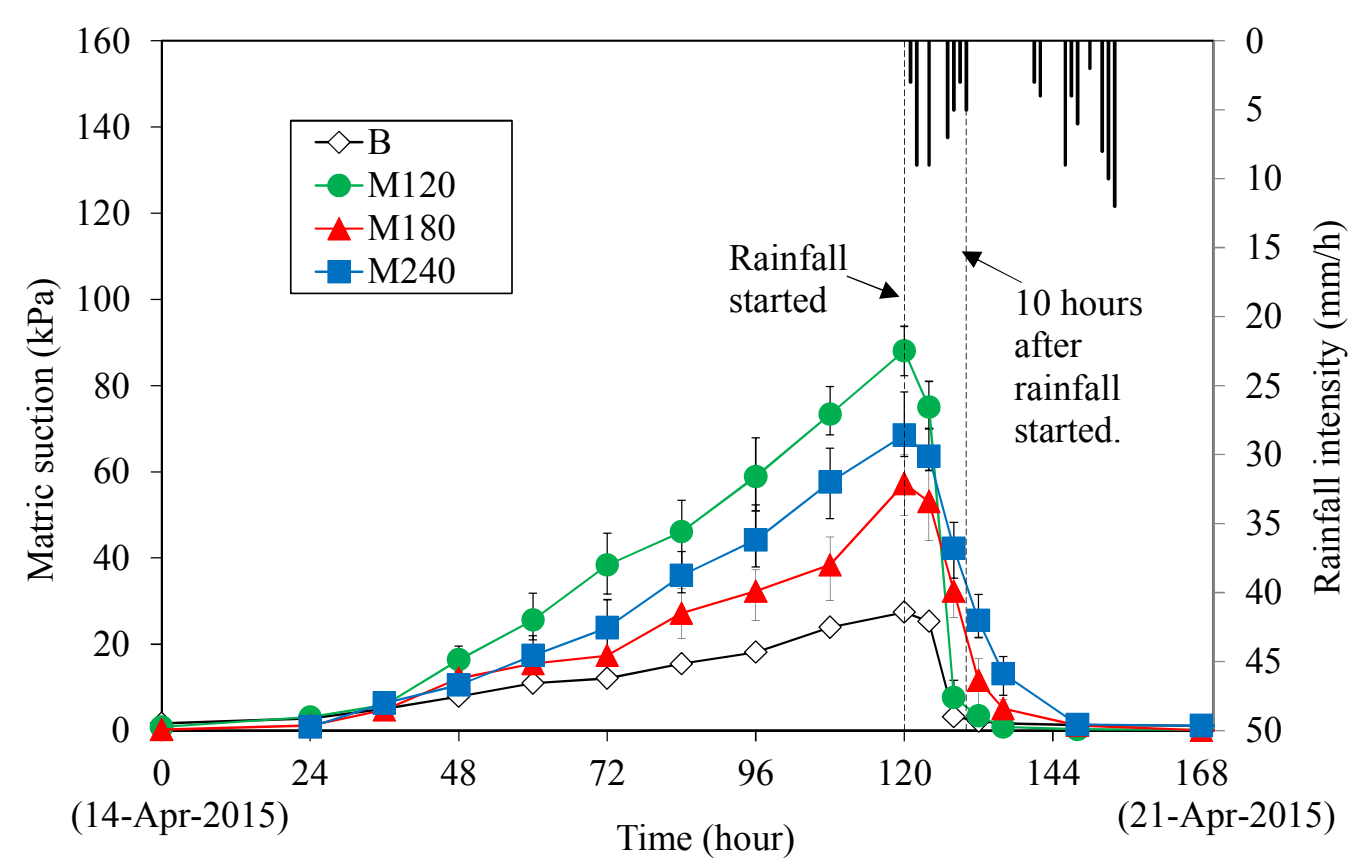

(a)

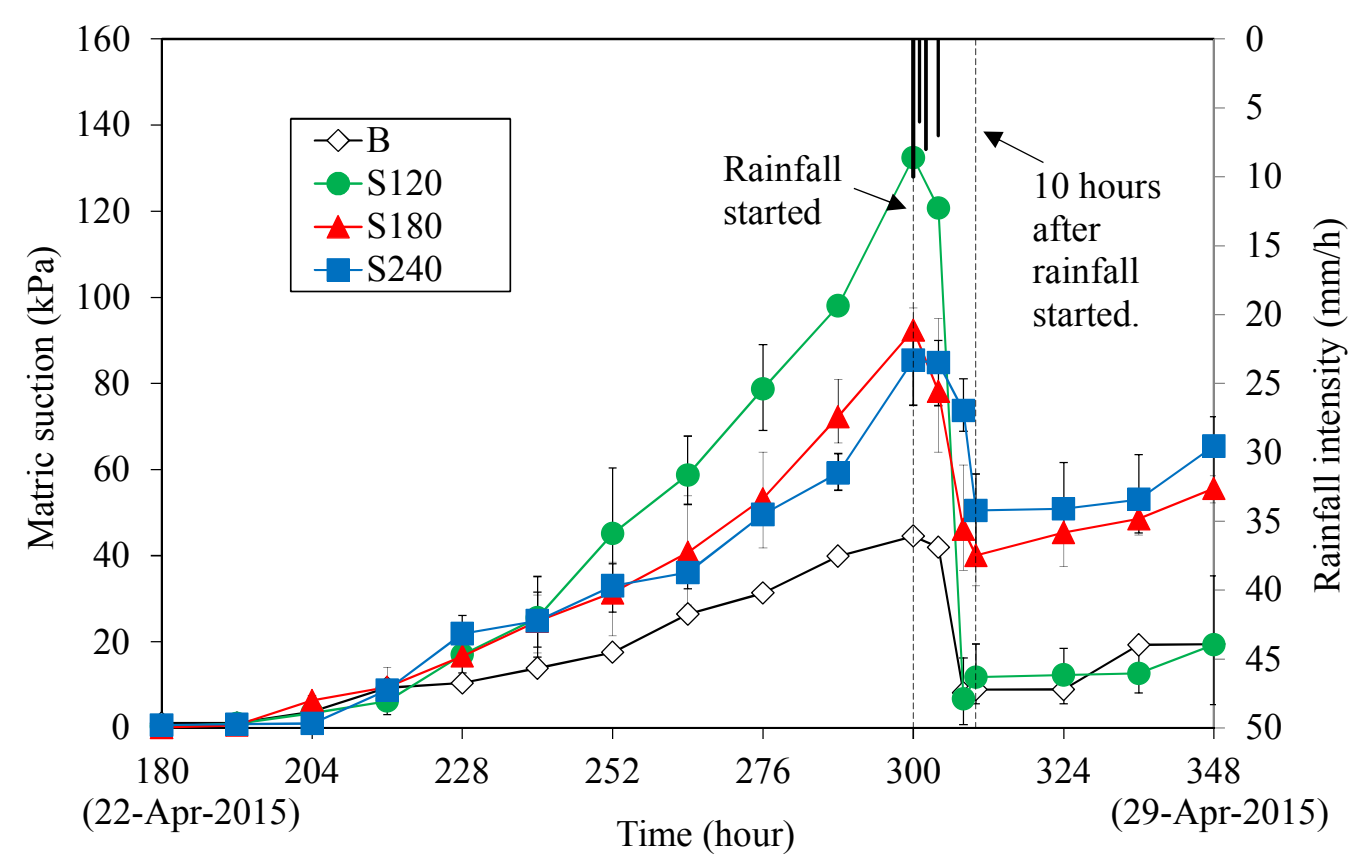

(b)

Fig. 6. Measured variations of matric suction at depth $100 \mathrm{~mm}$ with time (a) with and (b) without grass 


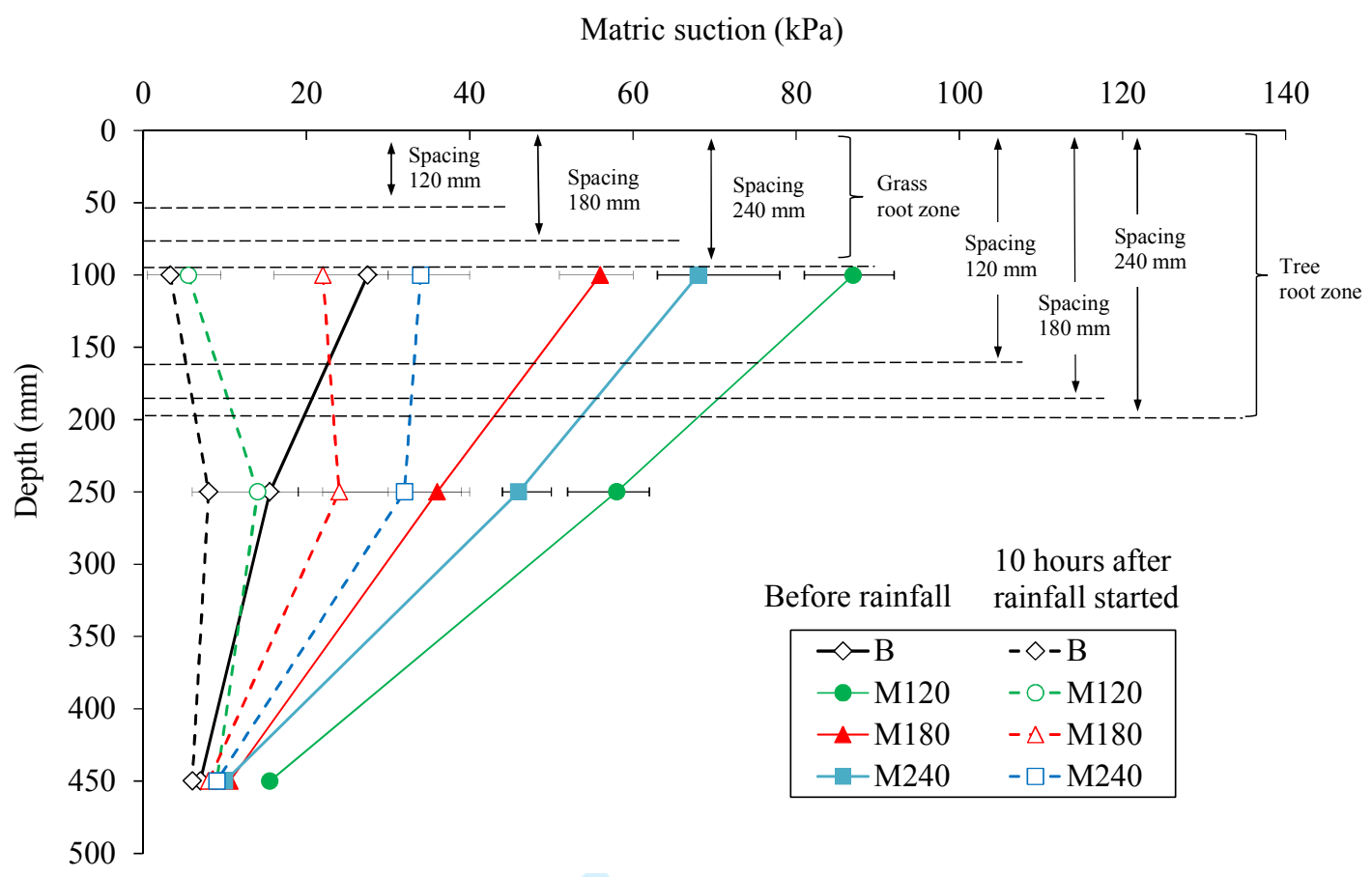

(a)

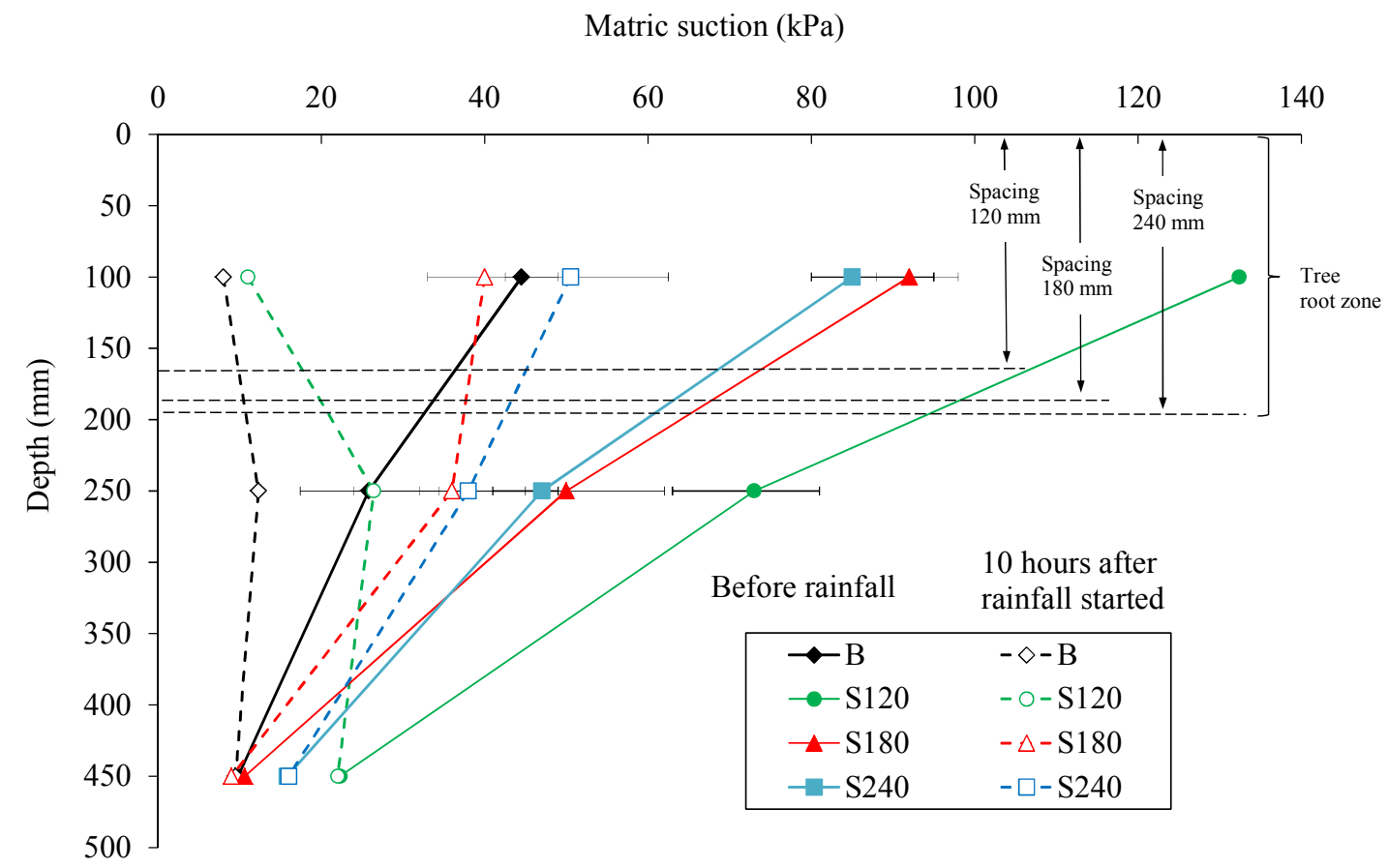

(b)

Fig. 7. Measured vertical distributions of matric suction along depth during rainfall (a) with and (b) without grass 


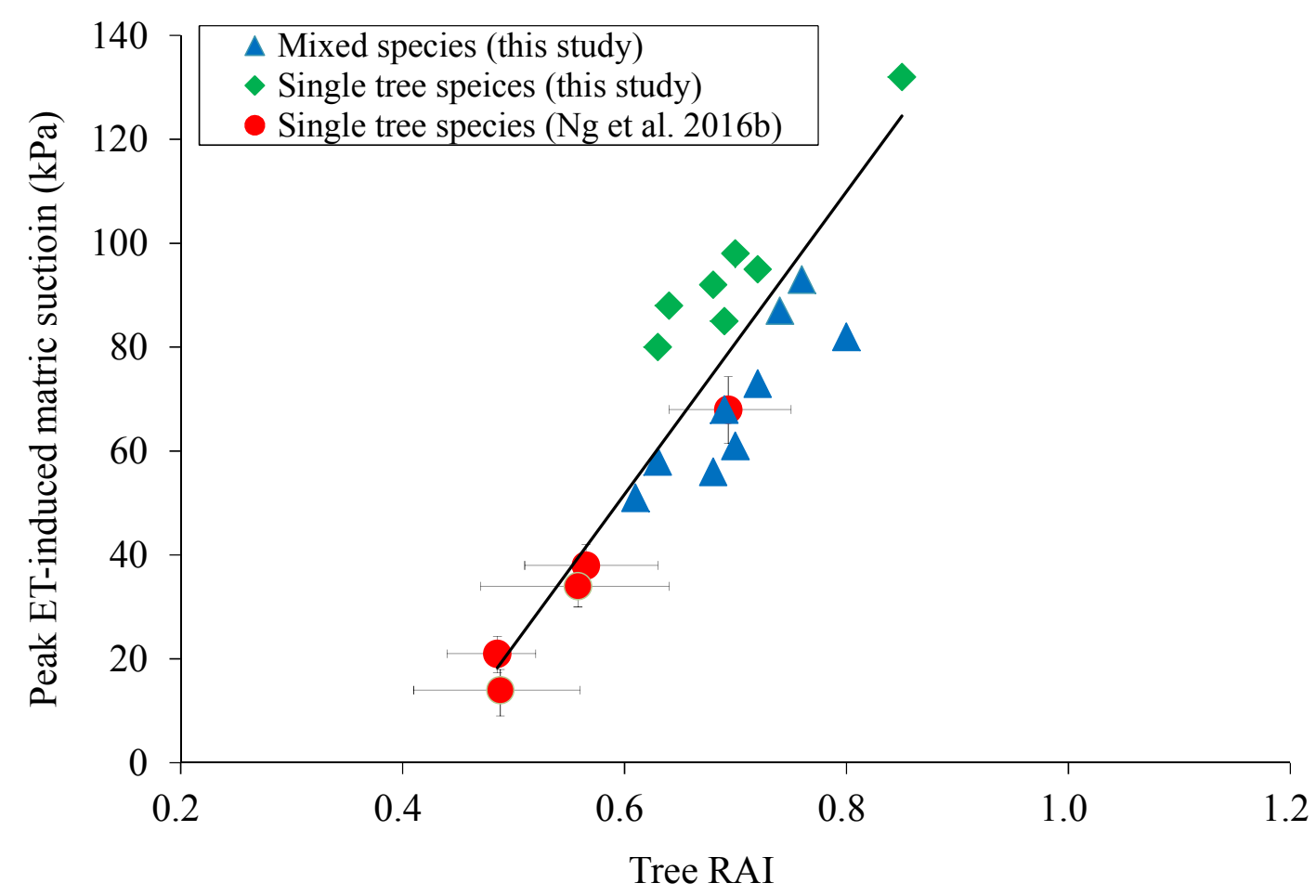

Fig. 8. Correlations between tree RAI and peak ET-induced matric suction at depth $100 \mathrm{~mm}$ 


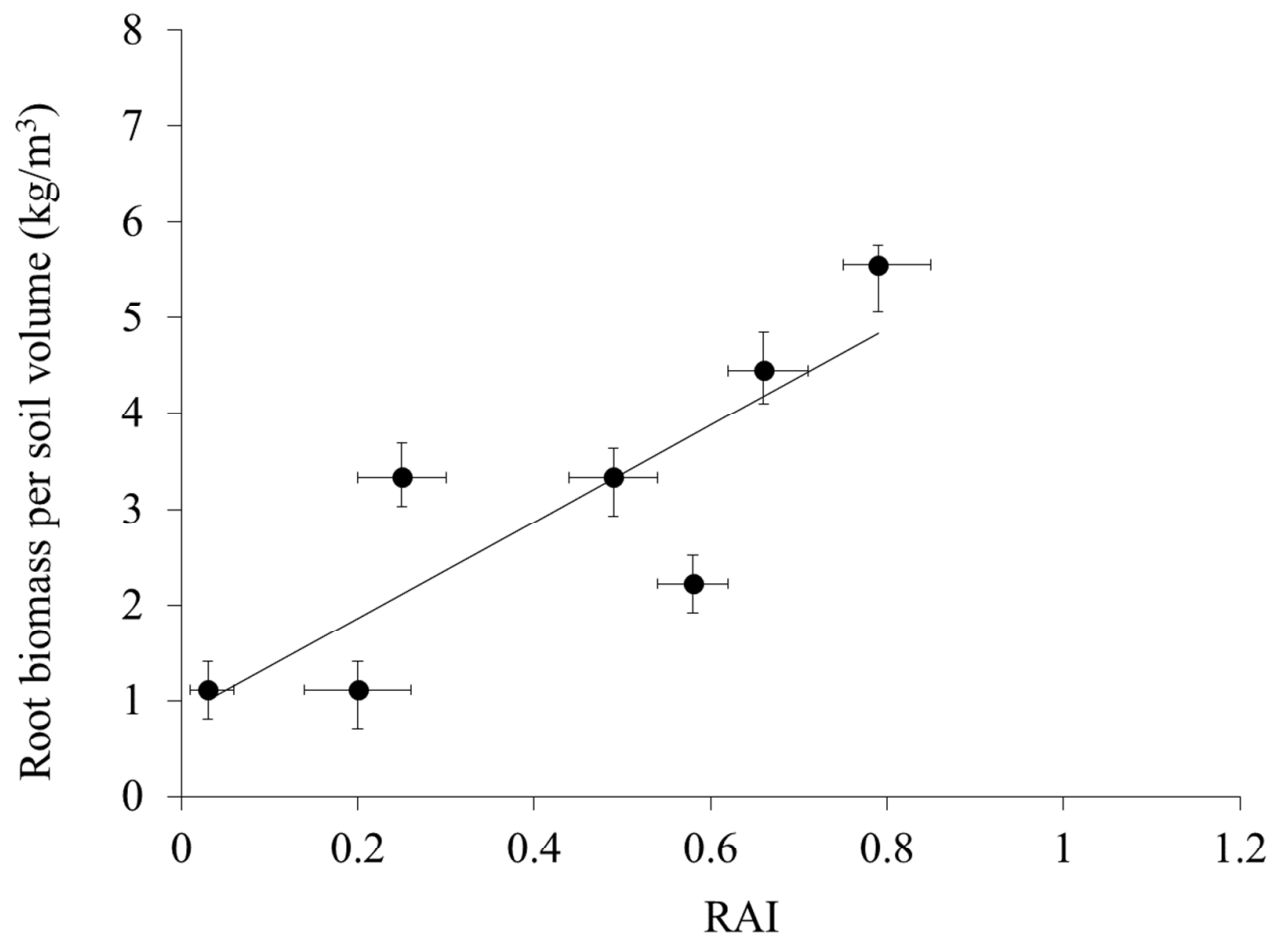

Fig. 9. Correlation between RAI and root biomass per soil volume. Error bars refer to standard error (sample number $=3$ ) (raw data from Garg et al. $(2015 b)$ and Leung et al., (2015b)) 


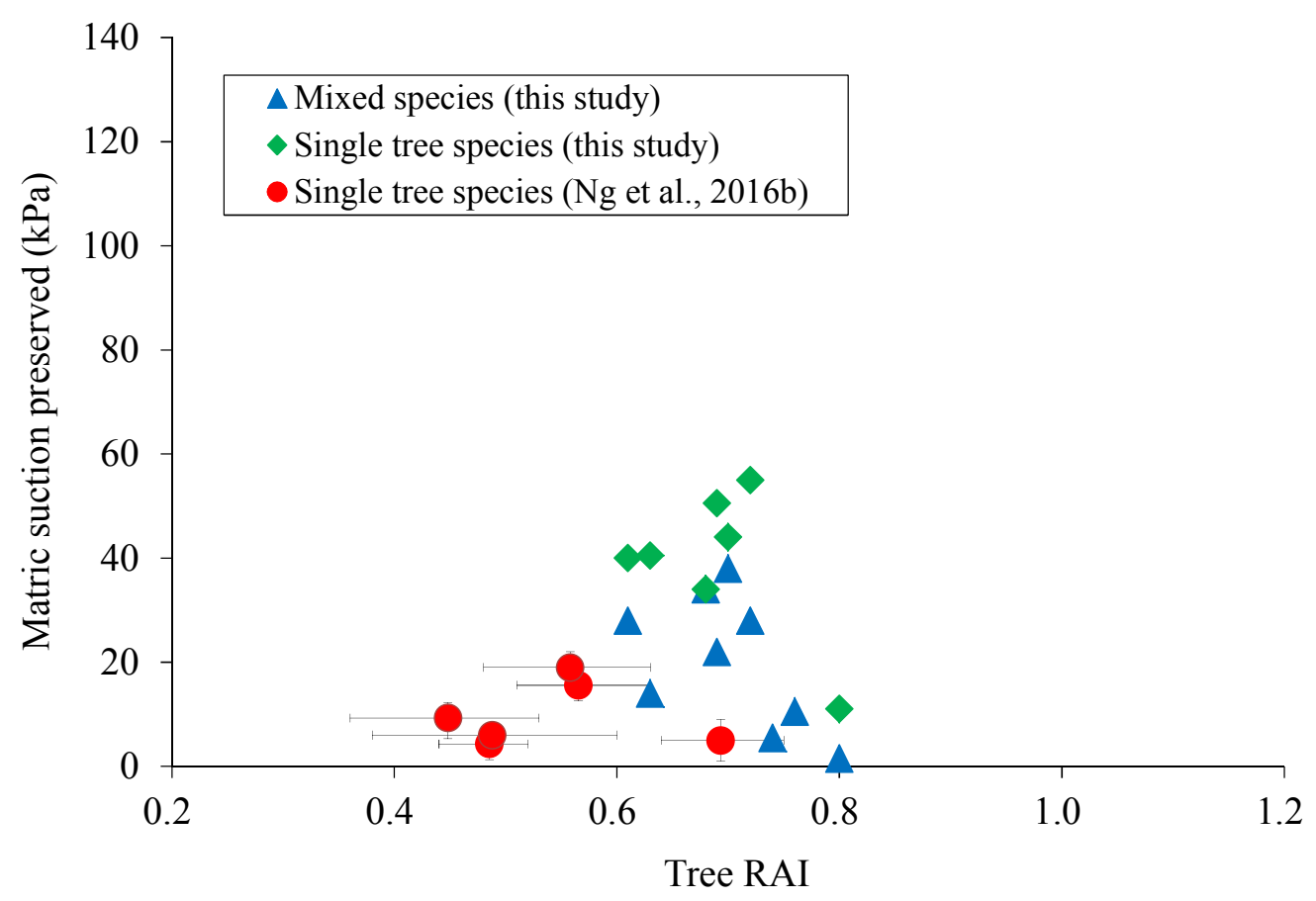

(a)

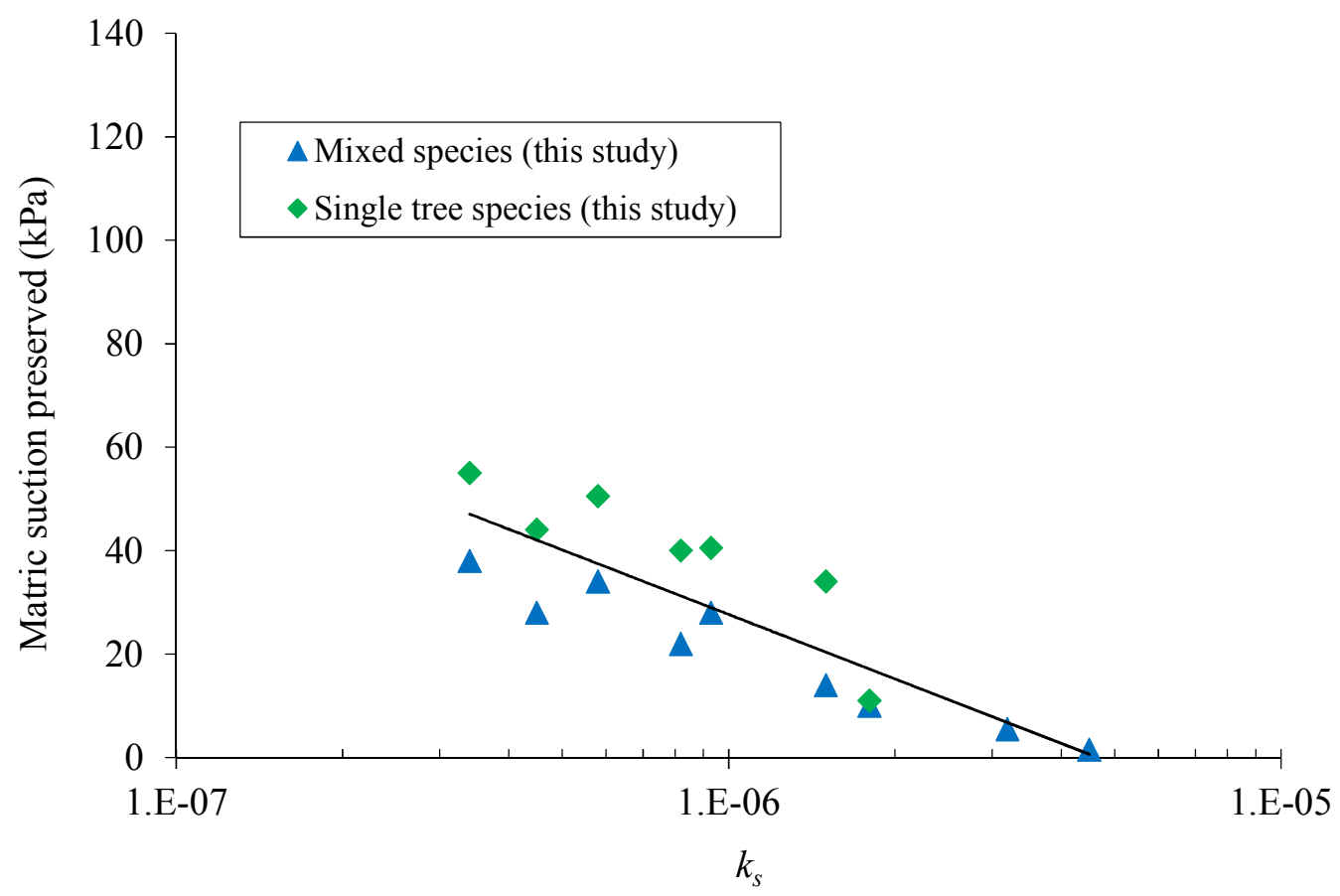

(b)

Fig. 10. (a) Correlations of matric suction preserved after 10 hours of rainfall at depth $100 \mathrm{~mm}$ with (a) tree RAI; and (b) $k_{s}$ 